\title{
'We Are Not Guinea Pigs': The Effects of Negative News on Vaccine Compliance*
}

\author{
Belinda Archibong ${ }^{\dagger}$ \\ Barnard College
}

\author{
Francis Annan ${ }^{\ddagger}$ \\ Georgia State University
}

January 14, 2021

\begin{abstract}
In 1996, following an epidemic, Pfizer tested a new drug on 200 children in Muslim Nigeria. 11 children died and multiple were disabled. We study the effects of negative news on vaccine compliance using evidence from the 2000 disclosure of deaths of Muslim children in the Pfizer trials. Muslim mothers reduced routine vaccination of children born after the 2000 disclosure. The effect was stronger for educated mothers and mothers residing in minority Muslim neighborhoods with relatively stronger ties to religious networks. The disclosure did not affect other health-seeking behavior of mothers, and the reduction effect is specific to child vaccination.
\end{abstract}

JEL classification: I12, I14, I18, D83, O12, Z12

Keywords: Vaccination, Vaccine Compliance, Epidemic, Disease, Networks, Information, Religion

${ }^{*}$ Thanks to Ebonya Washington, Liz Ananat, Matt Neidell, Erzo Luttmer, Marcella Alsan and participants at the AEA conference and Columbia University seminars for useful comments and suggestions. Errors are our own.

${ }^{\dagger}$ Corresponding author. Barnard College, Columbia University. 3009 Broadway, New York, NY 10027, USA. ba2207@columbia.edu.

$\ddagger$ Robinson College of Business, Georgia State University, 35 Broad St NW, Atlanta, GA 30303. fannan@gsu.edu 


\section{Introduction}

"We are not guinea pigs"

- South African anti-vaccine protesters, Reuters, July 1, 2020

Following a meningitis epidemic in 1996, Pfizer conducted human trials on 200 children in the Muslim state of Kano in Northern Nigeria of an experimental antibiotic, Trovan. 11 children died following the trials, with multiple participants disabled as well. A reporter at the Washington Post (WP) published an exposé alleging Pfizer's fault in the children's death and for unethical medical trials in 2000. The news sent shockwaves throughout Nigeria sparking a series of protests led by Muslim religious leaders alleging that Pfizer and 'the West' were trying to kill Muslims and calling for boycotts of vaccinations among Muslims. The resulting reduction in routine child vaccination among Muslim mothers set back global polio eradication efforts by over a decade, with negative effects lasting for up to 12 years after the initial disclosure. The event provides evidence to study the effects of negative news about vaccination on vaccine mistrust and non-compliance.

We assess the effects of the $2000 \mathrm{WP}$ disclosure on child vaccination outcomes using a difference-in-differences strategy comparing differences in child vaccination outcomes across Muslim vs. non-Muslim mothers (first difference), for children born before versus after the Washington Post revelation of the Pfizer drug trials in 2000 (second difference). We focus on Muslim mothers, given that the victims were Muslim children and that the boycotts against vaccination were led by Muslim religious leaders in the aftermath of the drug trial disclosure in 2000. The results show that the Washington Post disclosure of the Pfizer trials led to significant reductions in routine vaccination- namely, tuberculosis (BCG), diphtheria, pertussis and tetanus (DPT), polio and measles vaccinations, of children born to Muslim mothers after the disclosure. Muslim mothers reduced for BCG, DPT and polio vaccinations 
rates by 4.4 percentage points (pp), $4.7 \mathrm{pp}$ and $3.8 \mathrm{pp}$ respectively, equivalent to an $8 \%$ to $11 \%$ reduction in child vaccination of children born to Muslim mothers relative the pre-disclosure sample mean. We show that the effects are largely driven by educated Muslim mothers and Muslim mothers residing in minority Muslim neighborhoods with relatively stronger ties to religious networks. The disclosure did not affect other health-seeking behavior of mothers and the reduction effect is specific to child vaccination, not other child health outcomes.

The results provide insight into the drivers of vaccine hesitancy and non-compliance, with over 1.5 million people, many of them children, dying each year from vaccine preventable diseases ${ }^{1}$. We add to several distinct literatures. First our work is related to the recent economics literature on the role of medical malpractice on long term trust in health institutions and health behavior (Alsan and Wanamaker, 2018; Lowes and Montero, 2020; Martinez-Bravo and Stegmann, 2018); including work on the effects of the Tuskegee trials on health outcomes of African-American men (Alsan and Wanamaker, 2018), and the effects of colonial medical campaigns on mistrust in medicine in Africa (Lowes and Montero, 2020). Here we focus on the effects of negative news about vaccination on mothers' vaccination of their children with consequences for global health; drawing on literature linking education and health and vaccination behavior of mothers to explore heterogeneity by the mother's level of education (Cutler and Lleras-Muney, 2010; Kenkel, 1991; Anderberg, Chevalier, and Wadsworth, 2011).

Our work also adds to the nascent literature on the economics of religion, with past work, focused on Christians/churches, linking participation in religious networks to economic development (Iannaccone, 1998; Iyer, 2016), and demand for insurance (Auriol et al., 2020). Here, we provide evidence from Muslim populations, an understudied group in this literature, and focus on the important role of religious networks in diffusing information on health,

\footnotetext{
${ }^{1}$ Source: Children's Hospital of Philadelphia: https://www.chop.edu/centers-programs/vaccineeducation-center/global-immunization/diseases-and-vaccines-world-view
} 
particularly among minority communities where individuals may cleave more strongly to these networks in the absence of neighboring family ties. Past research has shown that these networks can be particularly important ways of spreading information to improve health among minority communities like African-Americans (Ellison and Sherkat, 1995) and Samoan immigrants in the United States (Levy-Storms and Wallace, 2003). Our paper illustrates how religious networks can reduce health behavior by diffusing negative news about vaccines, with lasting consequences for vaccine compliance.

\section{Context: The Pfizer Epidemic Drug Trials in Nigeria}

In 1996, Nigeria experienced one of the worst meningitis epidemics in the country's history, with 109,580 cases, 11,717 deaths and a case fatality rate of 10.7\% (Mohammed et al., 2000). Bacterial meningitis is an infection of the lining of the brain that is especially virulent in children, and endemic in northern Nigeria (Archibong and Annan, 2017). Northern Nigeria, and the infectious disease hospital in Kano state, where thousands of parents queued for treatment of sick children, is also a majority Muslim region, with around $99 \%$ of residents identifying as Muslim in Kano state as shown in the map in Figure 1. At the hospital in Kano, the non-profit Doctors Without Borders treated children with chloramphenicol, a well-known antibiotic endorsed by the World Health Organization (WHO) to treat bacterial meningitis (Perlroth, 2008).

Over the same period, Pfizer, a US pharmaceutical company, was trying to launch its new antibiotic drug, Trovan. While Pfizer had tested the drugs on adults, it had not yet been tested on children (Perlroth, 2008). Additionally, early testing on adults had shown some serious side effects of the drugs, including liver problems and cartilage abnormalities (Perlroth, 2008). After being alerted to the news of the meningitis epidemic in Nigeria, Pfizer decided to use the epidemic as an opportunity to test the efficacy of Trovan in pediatric 
settings. Pfizer staff flew to Kano, set up a site beside the Doctor Without Borders testing area and over 2 weeks, selected a sample of 200 children aged between 3 months and 18 years old to participate in drug trials for Trovan. 100 children were given full daily doses of Trovan over the course of a 5 day treatment in the treatment group. The other 100 children in the control group were given ceftriaxone, an antibiotic widely recognized as standard treatment for meningitis. The children in the control group were given a lower than normal dose of ceftriaxone, allegedly only a third of the WHO recommended dose at the time, over 4 of the 5 days of the treatment course (Perlroth, 2008; Ahmad, 2001).

A month later, 11 of the children that had participated in the Pfizer trials were dead. Additionally, numerous parents of children involved in the trials reported disabilities among their children, including paralysis and liver failure. In December 2000, a reporter at the Washington Post broke the story of the Pfizer epidemic drug trials in a series of exposés, alleging Pfizer's fault in the deaths and disabilities of multiple children and accusing Pfizer of conducting unethical experimental trials on children without attaining informed consent of participants (Stephens, 2000; Ezeome and Simon, 2010). A snapshot of the headlines is shown in Figure A1 in the Appendix. Parents alleged that they had not been informed of the experimental nature of the Pfizer trials, with many reporting that they thought they were receiving the standard medication issued in the neighboring Doctors Without Borders area at the hospital site in Kano (Ahmad, 2001; Perlroth, 2008; Wise, 2001)2.

The disclosure sent shockwaves throughout Nigeria, prompting a series of protests in Muslims states in northern Nigeria in 2001. Protesters, led by Muslim religious leaders, highlighted the death of Muslim children and the fact that the trials had been conducted in a Muslim state as evidence for the claim that Pfizer and its associated 'Western' institutions were targeting and trying to kill Muslims with vaccines (Yahya, 2007). Pfizer denied

\footnotetext{
${ }^{2}$ After approving Trovan for other uses in 1997, the US Food and Drug Administration (FDA) advised Pfizer to pull the drug citing safety concerns over deaths from Trovan-linked liver injuries (Perlroth, 2008).
} 
any wrongdoing, stating that the children died of meningitis not their drug (Ahmad, 2001; Perlroth, 2008).

\subsection{The Aftermath}

Following the Washington Post revelation, a panel of experts hired by the Nigerian government conducted its own investigation, and released a report finding Pfizer at fault in the children's death and guilty of conducting human trials without informed consent (Ezeome and Simon, 2010; Lenzer, 2006; Stephens, 2006). The report cited the Washington Post article as how the officials discovered news of the trials, with a snapshot of the report shown in Figure A2. In the following years, a series of lawsuits were filed against Pfizer by parents of children involved in the trials and the Kano state government. An out of court settlement was reached for, allegedly, $\$ 75$ million to Kano state and $\$ 175,000$ to four families of dead children in 2009 .

The incident heightened distrust among Muslims towards vaccination campaigns led by 'Western' non-profits like the Global Polio Eradication Initiative (GPEI), a consortium including the WHO and the US Center for Disease Control (CDC), aimed at eradicating polio worldwide (with a particular focus on Nigeria where more than $40 \%$ of the 677 new polio cases worldwide were recorded in 2002) (Yahya, 2007; Frishman, 2009). Tensions culminated in a 2003 Muslim religious leader led boycott of the GPEI led polio mass vaccination campaigns in 5 Muslim Northern States in Nigeria, buoyed by rumors that the vaccination effort was part of an effort by Westerners to spread HIV among Muslims and cause infertility in Muslim girls. In interviews explaining support for the boycott, respondents explicitly cited the Pfizer

drug trials, with one respondent stating, "We cannot trust the white man or our federal government because many years ago they were in partnership when they brought medicine to poison our people" (Yahya, 2006; Jegede, 2007). 
The boycotts continued for over a year and ended only after federal government officials worked with local religious leaders to demonstrate the safety of the vaccine (Yahya, 2006; Ghinai et al., 2013). The boycott also led to a $30 \%$ increase in polio prevalence, setting back global polio eradication efforts by over a decade, with Nigeria becoming one of the last countries in the world to be declared polio free in 2020 (Ghinai et al., 2013; Yahya, 2007). The Pfizer trials remain a point of tension among Muslims in Nigeria, with the spectre of Muslim children's deaths often referenced anytime health authorities attempt to conduct mass vaccination campaigns in the country (Masquelier et al., 2012; Nasiru et al., 2012).

\section{Data and Empirical Strategy}

\subsection{Data}

To examine the effects of the 2000 Washington Post news revelation of the Pfizer drug trials on child vaccination outcomes, we use data from the birth recode (BR) of the Demographic and Health Surveys (DHS) for four rounds of surveys between 1990 and 2013. The dataset documents individual mother's reported vaccination of children born between 1985 and $2013^{3}$.

We assemble available information on routine vaccination in the DHS, namely: BCG (tuberculosis), polio, DPT (diphtheria, pertussis and tetanus) and measles vaccination. Our main outcome of interest is an indicator that equals one if the child has received the BCG or measles vaccine or any dose of the DPT or polio vaccines. The recommended schedule for routine vaccination of children by WHO standards is at or near birth for BCG, DPT and polio, and at 9 months for measles, with most children receiving recommended vaccines

\footnotetext{
${ }^{3}$ For the BR sample, mothers aged 15-49 are individually interviewed to gather information on every child ever born to the woman. For each of the women interviewed, the BR has one record for every birth. The dataset is missing data on children born between 1991 and 1997 as the DHS only collects responses for children born in the five years prior to the survey.
} 
within their year of birth (Organization, 2019). To examine the effects of the 2000 disclosure on mother's health seeking behavior, we collect data on mother's reported pre-natal care source from the DHS. Other child health outcomes examined include whether the child is currently stunted or underweight ${ }^{4}$. Summary statistics are provided in Table A1 in the Appendix.

To explore links between vaccination rates and cases of disease, we digitized 10 years of available archival data on disease incidence in Nigeria from 1985 to 1995 from the Federal Ministry of Health. Panel A Table A2 in the Appendix shows a significant negative correlation between child vaccination coverage in the prior year, $t-1$ and current year, $t$, disease incidence. In line findings from the scientific literature, vaccination coverage of up to $90 \%$ in the previous year is needed for herd immunity/positive external benefits of vaccination in reducing the caseload of disease (Chen and $\mathrm{Fu}, 2019)$.

Lastly, to explore mechanisms and the potential role of Muslim religious networks in disseminating information around the Pfizer drug trials and intensifying the effects of the news announcement on child vaccination outcomes, we assemble data on religiosity, and perceptions of corruption and trust in religious leaders, neighbors and state officials from available Afrobarometer surveys over 4 rounds from 2003 to 2014. The data appendix and Table A3 in Section A.2 provides further detail on these sources.

Figure 1 shows differences between mean vaccination rates for Muslim vs non-Muslim mothers for children born between 1985 and 2013. Across all vaccines, there is a notable widening of the Muslim-non-Muslim mother child vaccination gap for children born immediately after the 2000 Washington post announcement in 2001. While Muslim mothers generally report lower vaccination outcomes for children, there were smaller religious vaccination gaps for children born between 1985 and 1990. While there appears to be initial

\footnotetext{
${ }^{4} \mathrm{~A}$ child is considered underweight by WHO standards if they have a weight for age z-score (WFA z) of less than -2.0 while a child is considered stunted with a height for age z-score (HFA z) of less than -2.0
} 
convergence in vaccination rates between Muslim and non-Muslim Mothers for children born after 1998, the religious gap widens in the year immediately after the 2000 Washington Post (WP) announcement as shown in Figure 1. Following an initial decrease in the difference in 2002, it declines again after the 2003 polio boycotts and stays generally low until around 2012 for all vaccination outcomes.

We examine the differences in mean vaccination outcomes for Muslim versus nonMuslim mothers for children born pre and post the 2000 WP disclosure of the Pfizer drug trials in Table A1. Muslim mothers in the sample report significantly lower child vaccination rates on average than their non-Muslim counterparts. The results from the unconditional means show that Muslim mothers decreased vaccination rates of children born after the 2000 announcement by 12.5 pp from $43 \%$ to $31 \%$ for BCG vaccination, by 10.9 pp from $41 \%$ to $30 \%$ for DPT vaccination, and by 7 pp from $32 \%$ to $25 \%$ for measles vaccination. Responses for measles vaccination were more muted as there are relatively low rates of measles vaccination in the sample- a function of the much later recommended vaccination ages for measles (9 months) versus the other at birth recommended vaccines as mentioned previously. In contrast, non-Muslim mothers increased vaccination rates across all vaccines between the pre-2000 and post-2000 birth samples, with over $70 \%$ of children born to nonMuslim mothers post 2000 vaccinated for BCG, DPT and polio.

\subsection{Empirical Strategy}

Our main specification in an interacted difference-in-differences (DD) model comparing differences in child vaccination outcomes across Muslim vs non-Muslim mothers (first difference), for children born before versus after the Washington Post revelation of the Pfizer drug trials in 2000 (second difference). We focus on Muslim mothers, given that the victims were Muslim children and that the boycotts against vaccination were led by Muslim religious leaders in the aftermath of the drug trial disclosure in 2000 as discussed in Section 2. 
We estimate panel regressions linking child vaccination outcomes for child $i$ born in year $r$ and located in district $d$ and state $s$ at survey year $t$ to a measure of post 2000 birth year assignment, Post $2000_{r}$, that is interacted with the religion of the child's mother Muslimidst $_{\text {: }}$

$$
y_{i r d s t}=\gamma \underbrace{\operatorname{Post} 2000_{r} \times \operatorname{Muslim}_{i d s t}}+\beta \operatorname{Muslim}_{i d s t}+X_{i r d s t}^{\prime} \theta+\delta_{r}+\mu_{d}+\phi_{s t}+\epsilon_{i r d s t}
$$

Post $2000_{r}$ and Muslim $i d s t$ are binary indicators for children born post the 2000 news revelation and for mother's reported Muslim religious identity respectively. This specification includes birth year fixed effects, $\delta_{r}$ that control for potential life cycle changes across cohorts and district fixed effects $\mu_{d}$ which capture unobserved differences that are fixed across districts or local government areas (LGAs), the smallest administrative neighborhood unit in Nigeria ${ }^{5}$. The state-by-year fixed effects, $\phi_{s t}$ control for time-varying changes to vaccination outcomes that are common across states, e.g. differences in health policies and infrastructure across states; such relevant policies are generally taken at the state level in Nigeria (Khemani, 2006). The specification includes controls for the mother's age at birth and level of education, $X_{\text {irdst }}$.

Our key parameter of interest, $\gamma$, captures the post-2000 birth year effect of being a Muslim mother relative to non-Muslim mothers on child vaccination outcomes, controlling for differences in the Muslim-Non-Muslim mother child vaccination rates in each district $(\beta)$. If child vaccination rates had continued to converge in the post-2000 period, we would measure a value of $\gamma$ greater than or equal to 0 . Alternatively, divergence would generate a $\gamma$ value that is less than 0 . As expected given the results in the bottom panel of Figure

\footnotetext{
${ }^{5}$ Nigeria is a federation with 36 states, a capital at the Federal Capital Territory in Abuja and 776 local government areas (LGAs). See Archibong (2019) for institutional details on the country.
} 
1, the full-sample $\gamma$ is largely negative, indicating post-2000 divergence in child vaccination rates for Muslim mothers relative to their non-Muslim counterparts. These estimates, along with standard errors, are shown in the event study coefficients in Figure 2 and echo trends in Figure 1. The average post-2000 coefficients shown in the Figure are in line with a divergence interpretation; across almost all child vaccination outcomes, there is a sharp drop in vaccination for children born to Muslim mothers after the 2000 news disclosure, with vaccination rates reaching their lowest levels in 2001 for all vaccination outcomes except polio, where vaccination rates decline past 2001, and reach their lowest level in 2002.

To test that the effects of the 2000 disclosure on child vaccination outcomes of Muslim mothers, $\gamma$, will be stronger among mothers with more information on vaccination, as discussed in Section 1, we conduct heterogeneity analysis, estimating Equation 1 in the split sample among educated mothers, with non-zero years of schooling. To test that $\gamma$ will be stronger among Muslim mothers living in minority Muslim neighborhoods with relatively stronger religious networks, as discussed in Section 1, we estimate Equation 1 in the split sample among mothers living in minority Muslim neighborhoods, define relative to a $50 \%$ threshold.

\subsubsection{Validity of Design}

We show that the Muslim-non-Muslim child vaccination gap was generally not systematically different prior to the 2000 disclosure as shown in Figure 2 and Table A2 in the Appendix, and discussed in Section 3.2, in line with the standard identifying assumptions of the DD model. The DD strategy outlined in Equation 1 also requires that the estimates of $\gamma$ reflect the effect of the Pfizer drug trials news disclosure on the child vaccination outcomes of Muslim mothers as long as there are no other structured shocks to Muslim mothers that affected health access or health-seeking behavior, that were correlated with the timing of the disclosure. The fixed effects and controls included in Equation 1, flexibly control for the pre-disclosure Muslim- 
Non-Muslim mother child vaccination gap and for time-varying threats to identification such as national trends in vaccination campaigns that affected Muslim women.

Comparably, although access to health care, including the numbers of health personnel and quality of health infrastructure differs and has historically differed for residents in poorer, northern Muslim states from their richer, southern, less Muslim counterparts ${ }^{6}$, any timeinvariant geographic difference in these factors are absorbed by the district fixed effects. State-year effects net out any time-varying health benefits or costs associated with location that affected the general population and might confute interpretation of our results. If our attempts to control for any changes in health investments that affected Muslim mothers are insufficient, most policy changes coinciding with the timing of the 2000 news disclosure were aimed towards improving access for Muslim populations, and would therefore bias our estimates toward zero ${ }^{7}$.

\section{Effects of the 2000 Washington Post Disclosure of Pfizer Drug Trials on Child Vaccination Outcomes}

\subsection{Main Estimates}

Table 1 reports estimates of the effects of the 2000 Washington Post (WP) disclosure of the Pfizer epidemic drug trials on child vaccination outcomes ${ }^{8}$. Our main results are in column (1) across four panels A, B, C and D for whether or not the child received the BCG, any dose of the DPT, any dose of the polio vaccine or the measles vaccine respectively. Across all vaccination outcomes, except measles, the $2000 \mathrm{WP}$ revelation of the Pfizer drug trials

\footnotetext{
${ }^{6}$ Figure A6 and Figure A7 in the Appendix, provide a snapshot of access to and quality of health care by state in Nigeria from a comprehensive 2012 survey of health facilities. See (Archibong, 2019) for data details.

${ }^{7}$ We find increases in the share of nurses/midwives in health personnel in majority Muslim states between 1991 and 2012 in line with increases in health investments in these areas, with results shown in Table A10.

${ }^{8}$ Results with $\beta$ estimates from Equation 1 are provided in Table A4 and overall effects are summarized in Figure A4 in the Appendix.
} 
reduced child vaccination outcomes for children born to Muslim mothers after the disclosure year; the interaction estimates are negative and strongly significant at conventional levels. The $2000 \mathrm{WP}$ disclosure led to a significant reduction in BCG vaccination rates for children born to Muslim mothers after the disclosure by 4.4 percentage points (pp)- approximately $10 \%$ of the pre-disclosure Muslim mother sample mean.

Estimates of the effect of the 2000 WP disclosure on DPT vaccination in column (1) of Panel B, show that Muslim mothers reduced DPT vaccination rates by 4.7 pp- about $11 \%$ of the pre-disclosure Muslim mother sample mean. Results for the effects of the disclosure on polio vaccination rates are shown in column $\mathrm{C}$, with Muslim mothers reducing vaccination rates of children born after the 2000 revelation by 3.8 pp- approximately $8 \%$ of the predisclosure Muslim mother sample mean. The effects of the disclosure on measles vaccination rates in the overall sample are more muted for children born to Muslim mothers after 2000 as shown in Panel D. The measles results may reflect the fact that child vaccination rates for measles are generally very low in the sample as discussed in Section 3.1.

\subsection{Heterogeneous Effects by Education and Neighborhood Religious Compo- sition}

In column (2) to column (5) of Table 1, we explore heterogeneous effects by splitting the sample by education and district or neighborhood religious composition. First, we explore the role of education by dividing the sample into educated (with non-zero years of education) and non-educated (with zero years of education) mothers in columns (2) and (3) respectively. The educated and non-educated samples are roughly equally sized as shown in Table 1 . In contrast to results in Alsan and Wanamaker (2018), here we hypothesize that the effects of the 2000 Pfizer drug trial disclosure should be stronger for educated mothers, who would have access to more information, be literate and hence more likely to have read the news and be more informed on health practices as shown in previous literature linking education 
and news consumption in Nigeria (Larreguy and Marshall, 2017).

The results show that the effects of the $2000 \mathrm{WP}$ disclosure on vaccination of children born to Muslim mothers are driven by educated mothers across all vaccination outcomes. Educated Muslim mothers reduce BCG, DPT, and polio vaccination of their children by $4.7 \mathrm{pp}, 7.4 \mathrm{pp}$, and $5.5 \mathrm{pp}$ respectively, an approximately $6 \%, 11 \%$, and $7 \%$ reduction in vaccination relative to the pre-disclosure Muslim mother sample means. The reduction in the measles vaccination for children born to educated Muslim mothers after the 2000 WP disclosure is a negative and significant effect of $4.4 \mathrm{pp}$, an $8 \%$ reduction relative to the predisclosure Muslim mother sample mean. There is no significant long-term effect of the 2000 WP disclosure on the vaccination outcomes of non-educated Muslim mothers as shown in column (3) of Table 1.

Following the literature on minority group cleavage to own social networks where, for example, religious individuals may cleave more strongly to religious networks in areas where they are the minority and far from neighboring family ties, described in the Introduction, we hypothesize that the effects of the 2000 Pfizer drug trial disclosure may be stronger for Muslim mothers residing in Muslim minority neighborhoods than those in majority Muslim neighborhoods. These individuals may be relatively less trusting of their out-group neighbors and consequently adhere more strongly to religious networks and hence would be more exposed to anti-vaccine messaging from religious leaders. Using DHS averages on the share of Muslim mothers in each district over the entire 1990-2013 survey, we divide the sample into Muslim minority districts or neighborhoods where Muslims make up less than or equal to $50 \%$ of the neighborhood and Muslim majority districts where Muslims make up over $50 \%$ of the neighborhood. The majority Muslim sample has more observations than the minority Muslim sample. The results are shown in columns (4) and (5) of Table 1 for the Muslim minority and Muslim majority neighborhood samples respectively. 
The effects of the $2000 \mathrm{WP}$ disclosure of the Pfizer drug trials on child vaccination outcomes of Muslim mothers are significantly distinct for Muslim mothers residing in minority Muslim neighborhoods from majority Muslim neighborhoods at the $1 \%$ level. Across all child vaccination outcomes, Muslim mothers in minority Muslim neighborhoods significantly decrease their vaccination outcomes for children born after the 2000 disclosure by between $6 \mathrm{pp}$ (BCG) to $7.8 \mathrm{pp}$ (DPT); the point estimate for the effect of the disclosure on child vaccination outcomes for Muslim mothers in majority Muslim neighborhoods is essentially 0 as shown in column (5) of Table 1.

\subsection{Potential Mechanisms}

The results presented in Section 4, along with the historical context presented in Section 2 are consistent with the hypothesis that the reduction in vaccination outcomes among Muslim mothers post the $2000 \mathrm{WP}$ revelation of the Pfizer drug trials was driven by decreased demand from Muslim mothers with more information and relatively stronger ties to religious networks. These mothers were more educated and more likely to reside in minority Muslim neighborhoods, farther away from family networks and with relatively lower trust in neighbors, and hence more likely to exhibit stronger cleavage to religious networks.

To test the hypothesis on the role of stronger ties to religious networks among Muslims in explaining the results, we assemble Afrobarometer data on religious identity of respondents and reported religiosity and trust in religious leaders, neighbors and state officials. The Afrobarometer data only includes this data post 2000, with four rounds of surveys from 2003 to 2014, so we conduct a cohort study to examine the effects of Muslim religious identity on religiosity and trust attitudes for individuals who would have been adults, and hence more cognizant of the news disclosure in 2000.

In the cohort study analysis, we investigate whether there is a Muslim-Non-Muslim 
religious gap in trust and religiosity outcomes for individuals $a$ born in year $r$ residing in district $d$ and state $s$ at survey year $t$ and estimate equations of the following form, limiting the sample to adults, aged 18 or older, as of the time of the WP news disclosure in 2000:

$$
\text { Trust }_{\text {ardst }}=\eta \text { Muslim }_{\text {ardst }}+X_{\text {ardst }}^{\prime} \theta+\delta_{r}+\mu_{d}+\phi_{s t}+\epsilon_{\text {ardst }}
$$

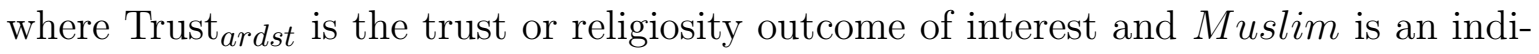
cator that equals one if the respondent indicates that she is Muslim. We include vectors of individual level covariates $X_{a d t}^{\prime}$, including controls for the gender and educational level of the respondent ${ }^{9}$. All regressions include year of birth $\left(\delta_{r}\right)$, district $\left(\mu_{d}\right)$ and state by year $\left(\phi_{s t}\right)$ fixed effects with standard errors are clustered at the district level, following the specification in Equation 1.

Our key parameter of interest, $\eta$, captures the effect of being a Muslim relative to nonMuslims on religiosity and trust outcomes for respondents who were adults as of the time of the 2000 WP news disclosure of the Pfizer drug trials. The religious outcomes we focus on are reported religiosity, or how often the respondent reports attending religious services and the respondent's perception of how many religious leaders are engaged in corruption, a "revealed preference" measure of trust ${ }^{10}$. We also examine respondents' reported levels of trust in neighbors, relatives and perceptions of corruption of police and elected local governing council members; these outcomes have been shown in previous research to be results of long-term historical processes like the slave trade (Nunn and Wantchekon, 2011) and colonial prison labor (Archibong and Obikili, 2020).

To test that there were no effects of the 2000 disclosure on religiosity and trust outcomes

\footnotetext{
${ }^{9}$ Data is described in detail in Appendix.

${ }^{10}$ There is a significant negative correlation between reported trust in religious leaders and the corruption perception measure, with the correlation equal to $-0.28(p<0.001)$. The results are similar using the trust and corruption perception measures.
} 
of Muslims, we examine differences in attitudes for adult Muslim cohorts in 2000 versus nonadult cohorts at the time of the disclosure. We estimate equations of the following form:

Trust $_{\text {ardst }}=\gamma \underbrace{\text { Post } 2000 \text { Adult }_{r} \times \text { Muslim }_{\text {ardst }}}+\beta \operatorname{Muslim}_{\text {ardst }}+X_{\text {ardst }}^{\prime} \theta++\delta_{r}+\mu_{d}+\phi_{s t}+\epsilon_{\text {ardst }}$

where Post 2000 Adult $_{r}$ is a binary indicator for adults as of the time of the 2000 WP news disclosure and all other variables are as in Equation 2. If there are no differences in adult-non-adult/child cohort as of 2000 disclosure religiosity and trust attitudes, then $\gamma$ will be insignificant in Equation 3.

In Panel A of Table 2, columns (1), (2) and (3) report results on religiosity, corruption perceptions of religious leaders, and trust in neighbors outcomes respectively for the adult cohort in 2000 (Equation 2); columns (4) to (6) shows cohort differences as described in Equation 3. Adult Muslims as of the time of the 2000 disclosure report higher levels of religiosity than non-Muslims, an effect size of $4 \%$ relative to the sample mean. The effect is stronger for adult cohorts in 2000 who would have been more cognizant of the Pfizer news and anti-vaccine messaging from religious leaders as shown by the significant interaction term in column (4). Adult Muslims as of the 2000 disclosure are $13 \%$ less likely to report their religious leaders are corrupt as shown in column (2) of Table 2, with no significant differences between adult and child cohorts in column (5). Adult Muslims as of the 2000 disclosure also report higher trust in neighbors (11\%) than their non-Muslim counterparts in column (3), with no significant differences by cohort in column (6).

We examine heterogeneous effects by the neighborhood religious composition, splitting the adult cohort in 2000 sample by residence into Muslim minority and Muslim majority neighborhoods. The results in Panel B show that adult Muslim respondents as of the time 
of the WP disclosure in 2000 living in Muslim minority neighborhoods are significantly more religious than their non-Muslim counterparts, an increase of $6 \%$ relative to the sample mean as shown in column (1). They are also $16 \%$ less likely to report beliefs that their religious leaders are corrupt as shown in column (2). There is no significant effect of Muslim identity on trust in neighbors for respondents in minority Muslim neighborhoods as shown in column (3) and Panel B of Table 2. In contrast, adult Muslim respondents as of the time of the 2000 WP disclosure residing in majority Muslim neighborhoods report no significant differential behavior for religiosity (column (4)) or perceptions of corruption of their religious leaders (column (5)).

The higher trust in neighbors results for Muslims reported in Panel A is almost entirely driven by Muslims residing in majority Muslim neighborhoods as shown in column (6) of Panel B. The results are summarized in Figure A5 and robust to changes in the majorityminority Muslim neighborhood cutoffs as shown in Table A6 in the Appendix ${ }^{11}$. There is no significant difference between Muslim and non-Muslim corruption perceptions of police and elected local governing councils and trust in relatives for adults at the time of the $2000 \mathrm{WP}$ disclosure as shown in columns (1), (2), (3) of Panel C. The evidence of higher religiosity and trust in religious leaders among Muslim respondents supports the hypothesis that the reduction in vaccination outcomes for children born to Muslim mothers post the disclosure was linked to information spread among Muslim mothers with stronger religious networks.

\subsection{Robustness}

To evaluate whether the 2000 WP revelation of the Pfizer drug trials affected health behavior and parent's investments in children's health more generally or just child vaccination behavior of Muslim mothers, we estimate Equation 1 with mother's pre-natal care source (own health-

\footnotetext{
${ }^{11}$ We provide suggestive evidence that the long-term effects of the WP disclosure on child vaccination outcomes are stronger for children born to Muslim mothers living in neighborhoods with higher religiosity and trust in religious leaders in Table A8.
} 
seeking behavior) and other child health outcomes (stunting and underweight). The results are shown in Table 3. There is no change in Muslim mother's use of nurses/midwives (nurses) or traditional birth attendants post 2000 as shown in Panel A. The only difference is a slight, significant decrease in the use of doctors for pre-natal care in column (1) of Panel A, driven entirely by reductions among non-educated mothers as shown in column (3). The decrease in the use of doctors among poorer, non-educated mothers is in line with previous literature highlighting an exodus of doctors from poorer regions in the Muslim north to richer regions in the less Muslim south or out of the country(Doctor et al., 2012). Table A10 in the appendix shows this decrease in the share of doctors in health personnel in majority Muslim areas in the post-2000 period.

Panel B of Table 3 shows no changes in underweight or infant mortality outcomes for children born to Muslim mothers post the 2000 WP disclosure in columns (4) and (7). If anything, children born to educated, Muslim mothers post 2000 are healthier, as measured by the lowered stunting outcomes in column (1) and (2); the results provide some support for the increased health investments among Muslim regions hypothesis discussed in Section 3.2.1. We provide additional robustness checks in the Appendix.

\section{Conclusion}

The 1996 Pfizer epidemic drug trials remain a point of tension and source of vaccine distrust for Muslims in Nigeria, over a decade over the initial news disclosure in 2000, with the spectre of the trials evoked with every new mass vaccination campaign (Yahya, 2006). Our results show significant reductions in routine vaccination of children born to Muslim mothers after the disclosure of the trials in 2000. The effects are driven by educated mothers and mothers living in Muslim minority neighborhoods with relatively lower trust/weaker ties to their neighborhoods/local communities and relatively stronger ties to religious networks. 
The reduction effect is specific to child vaccination outcomes with generally no reductions in Muslim mother's pre-natal care behavior and other child health outcomes.

These findings highlight the importance of both careful, ethical and transparent practices in vaccination efforts, and institutional and local community network trust in vaccine compliance. The negative externalities from reduced vaccination have global consequences for the resurgence of epidemics of infectious diseases that can persist for years after the initial event and disclosure. 

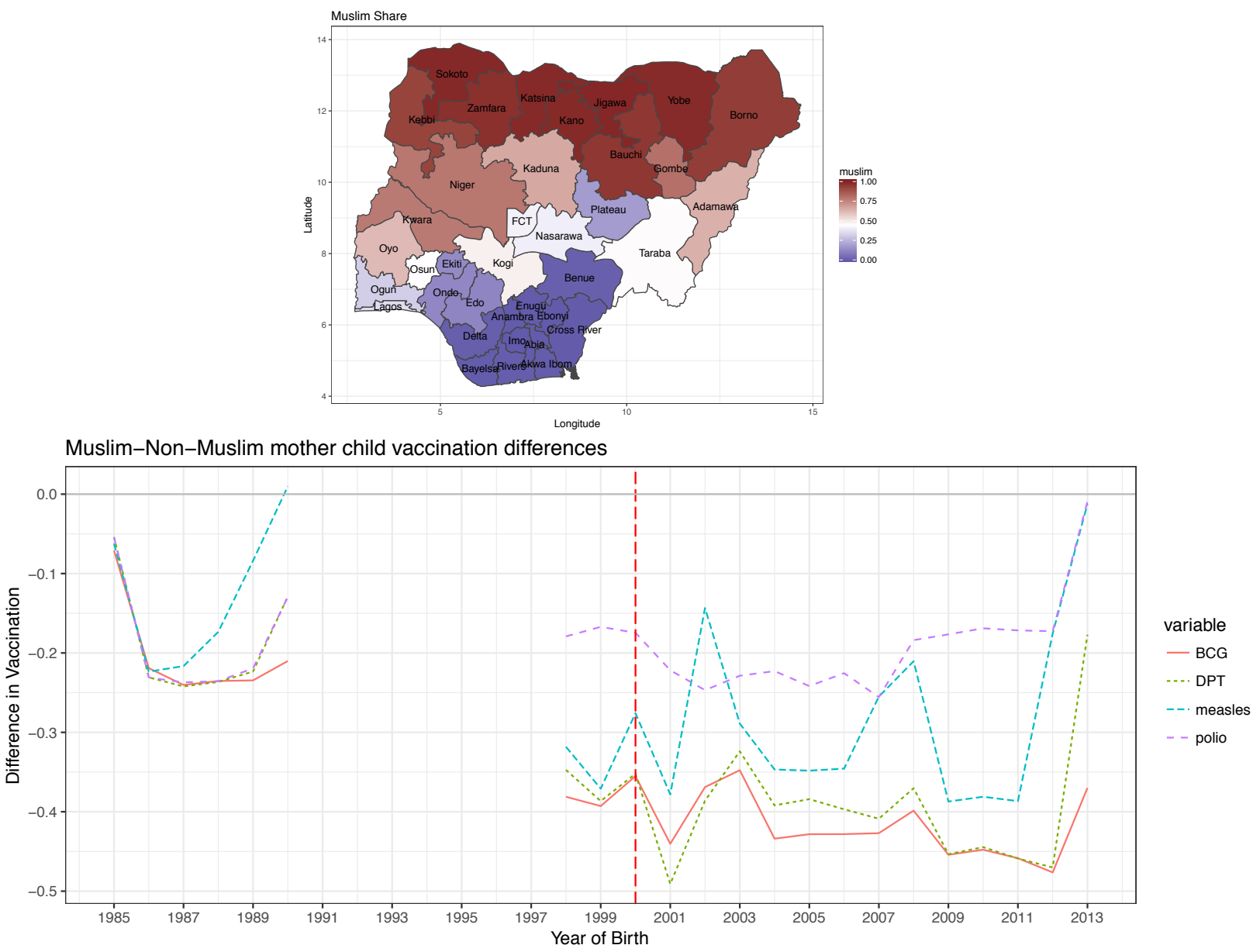

Figure 1: Muslim population shares by state with Kano drug trial state labelled and difference between Muslim vs non-Muslim mother mean child vaccination rates. 2000 WP news disclosure year labeled (Note: Missing data between 1991-1997) 

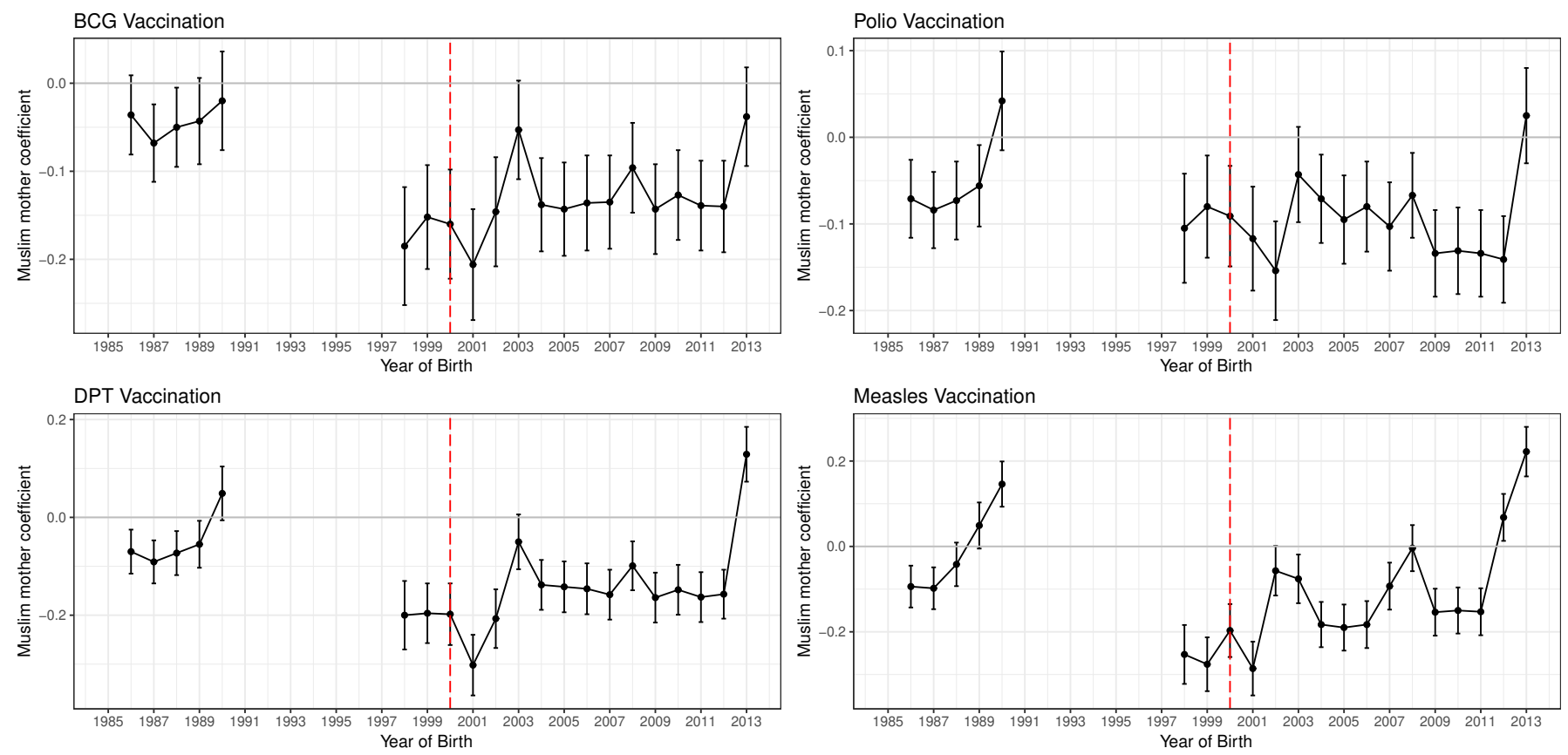

Figure 2: Event study coefficients of the effect of Muslim mother status on child vaccination outcomes by child's year of birth (Note: Missing data between 1991-1997) 
Table 1: Effects of 2000 Pfizer trial announcement on child vaccination outcomes

\begin{tabular}{lccccc}
\hline \hline \multirow{2}{*}{ Sample Within: } & \multicolumn{5}{c}{ Panel A: Child Vaccination Outcomes: BCG } \\
& All & Educated & Non-Educated & Minority Muslim & Majority Muslim \\
& $(1)$ & $(2)$ & $(3)$ & $(4)$ & $(5)$ \\
\hline Post 2000 x Muslim & $-0.044^{* *}$ & $-0.047^{* *}$ & -0.021 & $-0.060^{* *}$ & -0.021 \\
& $(0.017)$ & $(0.019)$ & $(0.033)$ & $(0.027)$ & $(0.034)$ \\
Mean of outcome & 0.503 & 0.745 & 0.248 & 0.747 & 0.313 \\
Observations & 66,243 & 33,955 & 32,288 & 28,904 & 37,339 \\
Clusters & 710 & 687 & 629 & 380 & 330 \\
\hline
\end{tabular}

\begin{tabular}{lccccc}
\hline \multirow{2}{*}{ Sample Within: } & \multicolumn{5}{c}{ Panel B: Child Vaccination Outcomes: DPT } \\
& $(1)$ & Educated & Non-Educated & Minority Muslim & Majority Muslim \\
& $(2)$ & $(3)$ & $(4)$ & $(5)$ \\
\hline Post 2000 x Muslim & $-0.043^{* *}$ & $-0.074^{* * *}$ & -0.011 & $-0.078^{* * *}$ & 0.006 \\
& $(0.018)$ & $(0.021)$ & $(0.034)$ & $(0.024)$ & $(0.038)$ \\
Mean of outcome & 0.487 & 0.715 & 0.247 & 0.720 & 0.307 \\
Observations & 65,752 & 33,691 & 32,061 & 28,633 & 37,119 \\
Clusters & 710 & 687 & 629 & 380 & 330 \\
\hline
\end{tabular}

\begin{tabular}{lccccc}
\hline \multirow{2}{*}{ Sample Within: } & \multicolumn{5}{c}{ Panel C: Child Vaccination Outcomes: Polio } \\
& All & Educated & Non-Educated & Minority Muslim & Majority Muslim \\
& $(1)$ & $(2)$ & $(3)$ & $(4)$ & $(5)$ \\
\hline Post 2000 x Muslim & $-0.038^{* *}$ & $-0.055^{* * *}$ & -0.003 & $-0.055^{* *}$ & -0.011 \\
& $(0.017)$ & $(0.019)$ & $(0.034)$ & $(0.022)$ & $(0.037)$ \\
Mean of outcome & & & & & 0.572 \\
Observations & 0.664 & 0.792 & 0.528 & 0.781 & 36,693 \\
Clusters & 65,351 & 33,632 & 31,719 & 28,658 & 330 \\
\hline
\end{tabular}

\begin{tabular}{lccccc}
\hline \multirow{2}{*}{ Sample Within: } & \multicolumn{5}{c}{ Panel D: Child Vaccination Outcomes: Measles } \\
& All & Educated & Non-Educated & Minority Muslim & Majority Muslim \\
& $(1)$ & $(2)$ & $(3)$ & $(4)$ & $(5)$ \\
\hline Post 2000 x Muslim & -0.003 & $-0.044^{*}$ & -0.002 & $-0.071^{* * *}$ & 0.002 \\
& $(0.019)$ & $(0.023)$ & $(0.029)$ & $(0.026)$ & $(0.037)$ \\
Mean of outcome & 0.379 & 0.548 & 0.201 & 0.545 & 0.250 \\
Observations & 65,865 & 33,724 & 32,141 & 28,722 & 37,143 \\
Clusters & 710 & 687 & 629 & 380 & 330 \\
\hline \hline Mother's controls & Yes & Yes & Yes & Yes & Yes \\
District FE & Yes & Yes & Yes & Yes & Yes \\
Year of birth FE & Yes & Yes & Yes & Yes & Yes \\
State x Year FE & Yes & Yes & Yes & Yes & Yes \\
\hline \hline
\end{tabular}

Notes: Regressions estimated by OLS. Robust standard errors in parentheses clustered by district. Districts are local government areas (LGAs) in Nigeria. Dependent variables are child vaccination outcomes for tuberculosis (BCG), diphtheria, pertussis and tetanus (DPT) and polio and measles as described in text. Sample is split between respondents living in districts that are over $50 \%$ muslim or Muslim Majority and respondents living in districts with $<=50 \%$ muslims or Muslim Minority districts in labeled columns. Post 2000 is an indicator that equals 1 if the child's year of birth is after the 2000 drug trial announcement. Muslim is an indicator that equals one if the mother reports that she is Muslim. Mother's controls include mother's age at birth and level of education, and drops education in non-educated (Education=0) subsamples. ${ }^{* *}$ Significant at the 1 percent level, ${ }^{* *}$ Significant at the 5 percent level, ${ }^{*}$ Significant at the 10 percent level. 
Table 2: Religiosity and trust among Muslims by post 2000 adult cohort status

\begin{tabular}{|c|c|c|c|c|c|c|}
\hline \multirow{4}{*}{$\begin{array}{l}\text { Outcome: } \\
\text { Sample Within: }\end{array}$} & \multicolumn{6}{|c|}{ Panel A: Muslim respondents, religiosity and trust in neighbor outcomes } \\
\hline & Religiosity & Corrupt Religious & Trust Neighbors & Religiosity & Corrupt Religious & Trust Neighbors \\
\hline & \multicolumn{6}{|c|}{ Adult $(>=18$ years $)$ Cohort in 2000} \\
\hline & $(1)$ & $(2)$ & $(3)$ & $(4)$ & $(5)$ & $(6)$ \\
\hline Muslim & \multirow[t]{2}{*}{$\begin{array}{l}0.166^{* *} \\
(0.072)\end{array}$} & \multirow[t]{2}{*}{$\begin{array}{c}-0.140^{* *} \\
(0.057)\end{array}$} & \multirow[t]{2}{*}{$\begin{array}{l}0.157^{* *} \\
(0.064)\end{array}$} & \multirow{2}{*}{$\begin{array}{c}0.047 \\
(0.082) \\
0.156^{* *} \\
(0.076)\end{array}$} & \multirow{2}{*}{$\begin{array}{c}-0.152^{* *} \\
(0.061) \\
0.050 \\
(0.058)\end{array}$} & \multirow{2}{*}{$\begin{array}{c}0.184^{* * *} \\
(0.062) \\
-0.038 \\
(0.060)\end{array}$} \\
\hline Post 2000 Adult x Muslim & & & & & & \\
\hline Mean of outcome & 3.996 & 1.076 & 1.414 & 4.069 & 1.101 & 1.364 \\
\hline Observations & 4,516 & 2,750 & 2,904 & 6,882 & 4,481 & 4,643 \\
\hline Clusters & 374 & 290 & 325 & 381 & 299 & 326 \\
\hline \multirow{4}{*}{$\begin{array}{l}\text { Outcome: } \\
\text { Sample Within: }\end{array}$} & \multicolumn{6}{|c|}{ Panel B: Muslim respondents and trust outcomes by minority $(<=50 \%)$ and majority $(>50 \%)$ status } \\
\hline & Religiosity & Corrupt Religious & Trust Neighbors & Religiosity & Corrupt Religious & Trust Neighbors \\
\hline & \multicolumn{3}{|c|}{ Muslim Minority (Adult Cohort in 2000) } & \multicolumn{3}{|c|}{ Muslim Majority (Adult Cohort in 2000) } \\
\hline & $(1)$ & $(2)$ & $(3)$ & $(4)$ & $(5)$ & $(6)$ \\
\hline Muslim & $\begin{array}{l}0.229^{* *} \\
(0.091)\end{array}$ & $\begin{array}{c}-0.185^{* *} \\
(0.082)\end{array}$ & $\begin{array}{c}0.078 \\
(0.095)\end{array}$ & $\begin{array}{c}0.031 \\
(0.134)\end{array}$ & $\begin{array}{c}-0.072 \\
(0.083)\end{array}$ & $\begin{array}{l}0.202^{* *} \\
(0.099)\end{array}$ \\
\hline Mean of outcome & 4.012 & 1.165 & 1.196 & 3.931 & 0.942 & 1.740 \\
\hline Observations & 2,663 & 1,636 & 1,645 & 1,651 & 977 & 1,112 \\
\hline Clusters & 209 & 163 & 172 & 141 & 109 & 130 \\
\hline
\end{tabular}

Panel C: Muslim respondents and other trust outcomes

Outcome:

Sample Within:

Corrupt Police Corrupt Local Gov. Trust Relatives Corrupt Police Corrupt Local Gov.

Trust Relatives

\begin{tabular}{|c|c|c|c|c|c|c|}
\hline \multirow[t]{2}{*}{ Nampie vriems. } & \multicolumn{3}{|c|}{ Hedur ( } & \multicolumn{3}{|c|}{ Н11 Nampic } \\
\hline & $(1)$ & $(2)$ & $(3)$ & $(4)$ & $(5)$ & $(6)$ \\
\hline Muslim & $\begin{array}{c}-0.005 \\
(0.044)\end{array}$ & $\begin{array}{c}0.006 \\
(0.041)\end{array}$ & $\begin{array}{c}0.111 \\
(0.073)\end{array}$ & $\begin{array}{r}-0.053 \\
(0.044)\end{array}$ & $\begin{array}{r}-0.042 \\
(0.042)\end{array}$ & $\begin{array}{l}0.182^{* * *} \\
(0.066)\end{array}$ \\
\hline Post 2000 Adult x Muslim & & & & $\begin{array}{c}0.060 \\
(0.037)\end{array}$ & $\begin{array}{c}0.049 \\
(0.041)\end{array}$ & $\begin{array}{c}-0.054 \\
(0.061)\end{array}$ \\
\hline Mean of outcome & 2.071 & 1.755 & 1.979 & 2.083 & 1.760 & 1.967 \\
\hline Observations & 5,805 & 5,727 & 2,581 & 9,022 & 8,887 & 4,564 \\
\hline Clusters & 481 & 481 & 358 & 484 & 484 & 360 \\
\hline Individual controls & Yes & Yes & Yes & Yes & Yes & Yes \\
\hline District FE & Yes & Yes & Yes & Yes & Yes & Yes \\
\hline Year of birth FE & Yes & Yes & Yes & Yes & Yes & Yes \\
\hline State $\mathrm{x}$ Year FE & Yes & Yes & Yes & Yes & Yes & Yes \\
\hline
\end{tabular}

Notes: Regressions estimated by OLS. Robust standard errors in parentheses clustered by district. Districts are local government areas (LGAs). Dependent variables are religiosity, trust in religious leaders and trust in neighbors from the Afrobarometer surveys from 2003-2014 where data available. Trust outcomes are reported trust levels on a scale of $0-3$, where "Not at all"= "0", "Just a little"="1", "Somewhat"="2", "A lot"="3"; Religiosity is reported frequency of religious service attendance, excluding weddings and funerals, where "Never"="0", "About once a year or less"=" 1 ", "About once every several months"="2", "About once a month" $=3$ ", "About once a week" = ", " More than once a week = 5 . Corruption outcomes are respondents" beliefs about how many people are involved in corruption where "None $=$ " , Some of them" =" 1 ", the

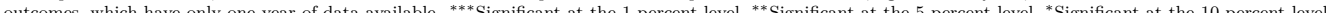


Table 3: Effects of 2000 Pfizer trial announcement on mother's health-seeking behavior (pre-natal care) and other child health outcomes

\begin{tabular}{|c|c|c|c|c|c|c|c|c|c|}
\hline \multirow{4}{*}{$\begin{array}{l}\text { Outcome: } \\
\text { Sample Within: }\end{array}$} & \multicolumn{9}{|c|}{ Panel A: Mother's Pre-Natal Care: Doctor, Nurse/Midwife, Traditional } \\
\hline & \multicolumn{3}{|c|}{ Doctor } & \multicolumn{3}{|c|}{ Nurse } & \multicolumn{3}{|c|}{ Traditional } \\
\hline & All & Educated & Non-Educated & All & Educated & Non-Educated & All & Educated & Non-Educated \\
\hline & $(1)$ & $(2)$ & $(3)$ & $(4)$ & $(5)$ & $(6)$ & $(7)$ & $(8)$ & (9) \\
\hline Post 2000 x Muslim & $\begin{array}{r}-0.033^{*} \\
(0.020)\end{array}$ & $\begin{array}{c}-0.021 \\
(0.022)\end{array}$ & $\begin{array}{c}-0.079^{* *} \\
(0.036)\end{array}$ & $\begin{array}{c}0.011 \\
(0.028)\end{array}$ & $\begin{array}{c}0.039 \\
(0.039)\end{array}$ & $\begin{array}{c}0.030 \\
(0.038)\end{array}$ & $\begin{array}{c}-0.009 \\
(0.008)\end{array}$ & $\begin{array}{c}-0.015 \\
(0.012)\end{array}$ & $\begin{array}{c}-0.010 \\
(0.013)\end{array}$ \\
\hline Mean of outcome & 0.256 & 0.393 & 0.112 & 0.446 & 0.616 & 0.270 & 0.027 & 0.034 & 0.020 \\
\hline Observations & 49,229 & 25,064 & 24,165 & 49,231 & 25,066 & 24,165 & 49,232 & 25,067 & 24,165 \\
\hline Clusters & 710 & 688 & 632 & 710 & 688 & 632 & 710 & 688 & 632 \\
\hline
\end{tabular}

\begin{tabular}{|c|c|c|c|c|c|c|c|c|c|}
\hline \multirow{4}{*}{$\begin{array}{l}\text { Outcome: } \\
\text { Sample Within: }\end{array}$} & \multicolumn{9}{|c|}{ Panel B: Child Health Outcomes: Stunting, Underweight and Infant Mortality } \\
\hline & \multicolumn{3}{|c|}{ Stunted } & \multicolumn{3}{|c|}{ Underweight } & \multicolumn{3}{|c|}{ Mortality } \\
\hline & All & Educated & Non-Educated & All & Educated & Non-Educated & All & Educated & Non-Educated \\
\hline & $(1)$ & $(2)$ & $(3)$ & $(4)$ & $(5)$ & $(6)$ & $(7)$ & $(8)$ & (9) \\
\hline Post 2000 x Muslim & $\begin{array}{c}-0.045^{* *} \\
(0.017)\end{array}$ & $\begin{array}{c}-0.061^{* * *} \\
(0.023)\end{array}$ & $\begin{array}{c}-0.031 \\
(0.030)\end{array}$ & $\begin{array}{c}-0.023 \\
(0.017)\end{array}$ & $\begin{array}{r}-0.036^{*} \\
(0.021)\end{array}$ & $\begin{array}{c}-0.022 \\
(0.033)\end{array}$ & $\begin{array}{c}-0.001 \\
(0.012)\end{array}$ & $\begin{array}{c}0.011 \\
(0.019)\end{array}$ & $\begin{array}{c}-0.008 \\
(0.021)\end{array}$ \\
\hline Mean of outcome & 0.357 & 0.259 & 0.469 & 0.302 & 0.207 & 0.412 & 0.408 & 0.471 & 0.376 \\
\hline Observations & 53,043 & 28,352 & 24,691 & 53,043 & 28,352 & 24,691 & 41,932 & 14,138 & 27,794 \\
\hline Clusters & 710 & 683 & 625 & 710 & 683 & 625 & 706 & 665 & 601 \\
\hline Mother's controls & Yes & Yes & Yes & Yes & Yes & Yes & Yes & Yes & Yes \\
\hline District FE & Yes & Yes & Yes & Yes & Yes & Yes & Yes & Yes & Yes \\
\hline Year of birth FE & Yes & Yes & Yes & Yes & Yes & Yes & Yes & Yes & Yes \\
\hline State $\mathrm{x}$ Year FE & Yes & Yes & Yes & Yes & Yes & Yes & Yes & Yes & Yes \\
\hline
\end{tabular}

Notes: Regressions estimated by OLS. Robust standard errors in parentheses clustered by district. Districts are local government areas (LGAs) in Nigeria. Dependent variables are mother's reported pre-natal care source: doctor, source: doctors, nurses/midwives or traditional healers, in Panel A; In Panel B, dependent variables are current child health outcomes for stunting and underweight in columns (1) to (6). A child is considered
underweight by WHO standards if they have a weight for age z-score (WFA z) of less than -2.0 while a child is considered stunted with a height for age z-score (HFA z) of less than -2.0. Infant mortality is the outcome in columns (7) to (9) of Panel B. Post 2000 is an indicator that equals 1 if the child's year of birth is after the 2000 drug trial announcement. Muslim is an indicator that equals one if the mother reports that she is Muslim. Mother's controls include mother's age at birth and level of education in columns (1), (2), (4), (5), (7) and (8) and drops education in non-educated subsamples. ${ }^{* * *}$ Significant at the 1 percent level, ${ }^{* *}$ Significant at the 5 percent level, ${ }^{*}$ Significant at the 10 percent level. 


\section{References}

Ahmad, Khabir. 2001. "Drug company sued over research trial in Nigeria." The Lancet 358 (9284): 815 .

Alsan, Marcella, and Marianne Wanamaker. 2018. "Tuskegee and the health of black men." Quarterly Journal of Economics 133 (1): 407-455.

Anderberg, Dan, Arnaud Chevalier, and Jonathan Wadsworth. 2011. "Anatomy of a health scare: education, income and the MMR controversy in the UK." Journal of Health Economics 30 (3): 515-530.

Archibong, Belinda. 2019. "Explaining divergence in the long-term effects of precolonial centralization on access to public infrastructure services in Nigeria." World Development 121: $123-140$.

Archibong, Belinda, and Francis Annan. 2017. "Disease and Gender Gaps in Human Capital Investment: Evidence from Niger's 1986 Meningitis Epidemic." American Economic Review 107 (5): 530-35.

Archibong, Belinda, and Nonso Obikili. 2020. "Prison labor: The price of prisons and the lasting effects of incarceration." African Economic History Working Paper Series (52).

Auriol, Emmanuelle, Julie Lassebie, Amma Panin, Eva Raiber, and Paul Seabright. 2020. "God insures those who pay? Formal insurance and religious offerings in Ghana." Quarterly Journal of Economics .

Chen, Xingru, and Feng Fu. 2019. "Imperfect vaccine and hysteresis." Proceedings of the royal society B 286 (1894): 20182406. 
Cutler, David M, and Adriana Lleras-Muney. 2010. "Understanding differences in health behaviors by education." Journal of Health Economics 29 (1): 1-28.

Doctor, Henry V, Sally E Findley, Alastair Ager, Giorgio Cometto, Godwin Y Afenyadu, Fatima Adamu, and Cathy Green. 2012. "Using community-based research to shape the design and delivery of maternal health services in Northern Nigeria." Reproductive Health Matters 20 (39): 104-112.

Ellison, Christopher G, and Darren E Sherkat. 1995. "The "semi-involuntary institution" revisited: Regional variations in church participation among black Americans." Social Forces 73 (4): 1415-1437.

Ezeome, Emmanuel R, and Christian Simon. 2010. "Ethical problems in conducting research in acute epidemics: the Pfizer meningitis study in Nigeria as an illustration." Developing World Bioethics 10 (1): 1-10.

Frishman, Alan. 2009. "Major reason for Nigerian boycott of polio vaccine." Health Affairs 28 (6): 1860-1861.

Ghinai, Isaac, Chris Willott, Ibrahim Dadari, and Heidi J Larson. 2013. "Listening to the rumours: What the northern Nigeria polio vaccine boycott can tell us ten years on." Global Public Health 8 (10): 1138-1150.

Iannaccone, Laurence R. 1998. "Introduction to the Economics of Religion." Journal of Economic Literature 36 (3): 1465-1495.

Iyer, Sriya. 2016. "The new economics of religion." Journal of Economic Literature 54 (2): $395-441$.

Jegede, Ayodele Samuel. 2007. "What led to the Nigerian boycott of the polio vaccination campaign?" PLoS Med 4 (3): e73. 
Kenkel, Donald S. 1991. "Health Behavior, Health Knowledge, and Schooling." Journal of Political Economy pp. 287-305.

Khemani, Stuti. 2006. "Local government accountability for health service delivery in Nigeria." Journal of African Economies 15 (2): 285-312.

Larreguy, Horacio, and John Marshall. 2017. "The effect of education on civic and political engagement in nonconsolidated democracies: Evidence from Nigeria." Review of Economics and Statistics 99 (3): 387-401.

Lenzer, Jeanne. 2006. "Secret report surfaces showing that Pfizer was at fault in Nigerian drug tests." British Medical Journal 332 (7552): 1233.

Levy-Storms, Lene, and Steven P Wallace. 2003. "Use of mammography screening among older Samoan women in Los Angeles county: a diffusion network approach." Social Science E Medicine 57 (6): 987-1000.

Lowes, Sara Rachel, and Eduardo Montero. 2020. "The legacy of colonial medicine in Central Africa." CEPR Discussion Paper No. DP12772, Conditionally accepted at American Economic Review .

Makinde, Olusesan Ayodeji, Abayomi Sule, Olayinka Ayankogbe, and David Boone. 2018. "Distribution of health facilities in Nigeria: implications and options for universal health coverage." The International journal of health planning and management 33 (4): e1179e1192.

Martinez-Bravo, Monica, and Andreas Stegmann. 2018. In Vaccines We Trust? The Effects of the CIA's Vaccine Ruse on Immunization in Pakistan. Technical report.

Masquelier, Adeline, H Dilger, A Kane, and S Langwick. 2012. "Public health or public 
threat? Polio eradication campaigns, Islamic revival, and the materialization of state power in Niger." Medicine, Mobility, and Power in Global Africa pp. 213-40.

Mohammed, Idris, Abdussalam Nasidi, AS Alkali, MA Garbati, EK Ajayi-Obe, Kudi A Audu, Abdulmumini Usman, and Suleiman Abdullahi. 2000. "A severe epidemic of meningococcal meningitis in Nigeria, 1996." Transactions of the Royal Society of Tropical Medicine and Hygiene 94 (3): 265-270.

Nasiru, Sani-Gwarzo, Gambo G Aliyu, Alex Gasasira, Muktar H Aliyu, Mahmud Zubair, Sunusi U Mandawari, Hassana Waziri, Abdulsalami Nasidi, and Samer S El-Kamary. 2012. "Breaking community barriers to polio vaccination in Northern Nigeria: the impact of a grass roots mobilization campaign (Majigi)." Pathogens and Global Health 106 (3): 166171.

Nunn, Nathan, and Leonard Wantchekon. 2011. "The slave trade and the origins of mistrust in Africa." American Economic Review 101 (7): 3221-52.

Organization, World Health. 2019. "WHO recommendations for routine immunizations summary tables.".

Perlroth, Nicole. 2008. "Pfizer's Nigerian Nightmare." Forbes .

Stephens, Joe. 2000. "Where profits and lives hang in balance." The Washington Post .

Stephens, Joe. 2006. "Panel faults Pfizer in'96 clinical trial in Nigeria." The Washington Post pp. A1-A21.

Wise, Jacqui. 2001. "Pfizer accused of testing new drug without ethical approval." British Medical Journal .

Yahya, Maryam. 2006. "Polio vaccines: difficult to swallow: the story of a controversy in northern Nigeria." Institute of Development Studies Working Paper 261. 
Yahya, Maryam. 2007. "Polio vaccines "no thank you!" Barriers to polio eradication in Northern Nigeria." African Affairs 106 (423): 185-204. 


\section{A Appendix (For Online Publication)}

\section{Contents}

1 Introduction $\quad 2$

2 Context: The Pfizer Epidemic Drug Trials in Nigeria 4

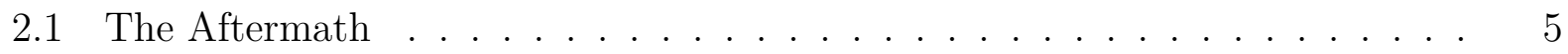

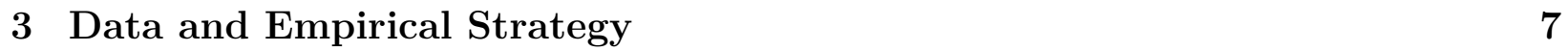

3.1 Data . . . . . . . . . . . . . . . . . . 7

3.2 Empirical Strategy . . . . . . . . . . . . . . . . . . . 9

3.2 .1 Validity of Design . . . . . . . . . . . . . . . . . . 11

4 Effects of the 2000 Washington Post Disclosure of Pfizer Drug Trials on $\begin{array}{lr}\text { Child Vaccination Outcomes } & 12\end{array}$

4.1 Main Estimates . . . . . . . . . . . . . . . . . . . . . . . . . . 12

4.2 Heterogeneous Effects by Education and Neighborhood Religious Composition 13

4.3 Potential Mechanisms . . . . . . . . . . . . . . . . . . . . . . . . 15

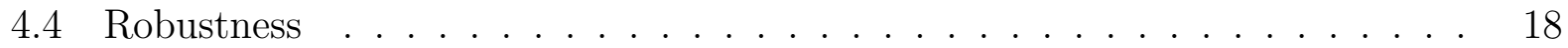

$\begin{array}{llr}5 & \text { Conclusion } & 19\end{array}$

A Appendix (For Online Publication) 30

A.1 2000 WP Disclosure and Ex-Post Government Report . . . . . . . . . . . 33

A.2 Data Appendix . . . . . . . . . . . . . . . . . . . . 34

A.2.1 Data and Variable Descriptions _... . . . . . . . . . . . 34

A.3 Robustness . . . . . . . . . . . . . . . . . . . . . . . 38

A.4 Health Facility Statistics . . . . . . . . . . . . . . . 46 


\section{List of Figures}

1 Muslim population shares by state with Kano drug trial state labelled and difference between Muslim vs non-Muslim mother mean child vaccination rates. 2000 WP news disclosure year labeled (Note: Missing data between 1991-1997) 20

2 Event study coefficients of the effect of Muslim mother status on child vaccination outcomes by child's year of birth (Note: Missing data between 1991-1997) 21

A1 The Washington Post Revelation . . . . . . . . . . . . . . . . 33

A2 Government Report highlighting Pfizer misconduct and role of Washington Post news . . . . . . . . . . . . . . . . . . . . . . . . 33

A3 Share of children born in 1989 and 2012 with vaccinations recorded in Nigeria by state. Source: DHS . . . . . . . . . . . . . . . . .

A4 Effect of 2000 Pfizer trials announcement by mother's education and neighborhood religious composition . . . . . . . . . . . . . . 38

A5 Religiosity and trust among Muslims by neighborhood religious composition 40

A6 Number of health facilities per 100,000 population and health infrastructure quality index by state, 2012. Source: OSSAP survey . . . . . . . . . . 46

A7 Staff availability at health facilities by state, 2012. Source: OSSAP survey . 47

\section{List of Tables}

1 Effects of 2000 Pfizer trial announcement on child vaccination outcomes . . . 22

2 Religiosity and trust among Muslims by post 2000 adult cohort status . . . 23

3 Effects of 2000 Pfizer trial announcement on mother's health-seeking behavior (pre-natal care) and other child health outcomes . . . . . . . . . . . . . . 24

A1 Summary Statistics, DHS _. . . . . . . . . . . . . . 35 
A2 Reduced form relationship between prior year, t-1, child vaccination coverage and disease incidence in year t (Panel A) and between Muslim mother status and child vaccination outcomes (Panel B) pre 2000 . . . . . . . . . 36

A3 Summary Statistics including Afrobarometer outcomes . . . . . . . . . . 37

A4 Effects of 2000 Pfizer trial announcement on child vaccination outcomes, showing main effects . . . . . . . . . . . . . . . . . . . . . . . . . . . 39

A5 Effects of 2000 Pfizer trial announcement on child vaccination outcomes, heterogeneity tests by minority status of Muslims in district . . . . . . . . . . . 41

A6 Religiosity and trust among Muslims by post 2000 adult cohort status, robustness to marginal changes in age cutoff . . . . . . . . . . . . . . . . 42

A7 Religiosity and trust among Muslims by post 2000 adult cohort and minority status of Muslims in districts . . . . . . . . . . . . . . . . . . 43

A8 Trust in religious leaders and child vaccination outcomes in 2012 . . . . . . 44

A9 Effects of 2000 Pfizer trial announcement on mother's health-seeking behavior (pre-natal care) and other child health outcomes . . . . . . . . . . . . 45

A10 Increase in share of nurse/midwives in total health personnel by Muslim state status post $2000 \ldots \ldots \ldots$. . . . . . . . . . . . . . . . . . . . . . . . 


\title{
A.1 2000 WP Disclosure and Ex-Post Government Report
}

\section{Sections $\equiv \quad$ Ofje Whghington ilogt \\ Where Profits and Lives Hang in Balance}

\author{
By Joe Stephens \\ December 17, 2000
}

By the time word of the little girl's death reached the United States, her name had been replaced by numerals: No. 6587-0069.

She was 10 years old and a scant 41 pounds. She lived in Nigeria, and in April 1996 she ached from meningitis.

An epidemic raged and scores lay dying in this frenetic city of amber dust. Somehow the girl found a refuge: a medical camp where foreign doctors had arrived to dispense expensive medicines for free.

Figure A1: The Washington Post Revelation

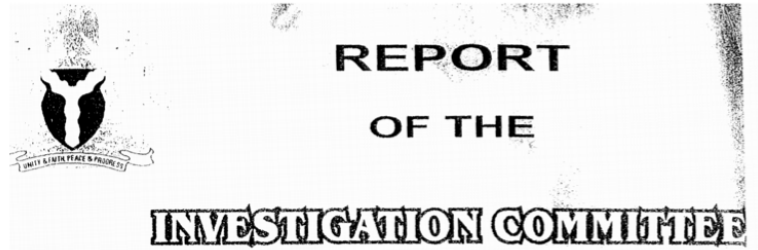

(O)

THE CLINICAL TRIAL OF TROVAFLOXACIN (TROVAN) BY PFIZER, KANO, 1996

\section{CHAPTER 1}

\subsection{INTRODUCTION}

The American Washington Post of 17th December 2000 reported the death of eleven Nigerian children and deformation of many others arising from clinical trials on Trovafloxacin (Trovan) a new antibiotic drug involving 200 critically ill children. It was reported that Pfizer Inc. conducted the clinical trials in Kano, Nigeria in April 1996 during a triple epidemic of measles, cholera and cerebrospinal meningitis (Appendix I)

The former Honorable Minister of Health, Dr. Tim Menakaya consequent upon this report issued a press statement (Appendix II) and set up a Committee to investigate this trial with a view to finding out what really happened (see Appendix III).

Figure A2: Government Report highlighting Pfizer misconduct and role of Washington Post news 


\section{A.2 Data Appendix}

\section{A.2.1 Data and Variable Descriptions}

- Demographic and Health Survey (DHS) Birth Recode (BR) data from 1990-2013 for 1985-2013 birth years. Including child vaccination outcomes for tuberculosis (BCG), diphtheria, pertussis and tetanus (DPT), measles and polio. Child health outcomes for stunting and underweight. Mother's health seeking behavior or reported pre-natal care source.

- Annual Abstract of Statistics for cases of infectious disease by state from 1985-1995. Health personnel statistics by state in 1991. Health statistics from 2012 from Nigeria Millennium Development Goals (MDG) Information System survey dataset: https://qsel.columbia.ed up-initiative/

- Afrobarometer data from 2003-2014 surveys. Trust outcomes are reported trust levels on a scale of $0-3$, where "Not at all" = "0", "Just a little"="1", "Somewhat"="2", "A lot"="3"; Religiosity is reported frequency of religious service attendance, excluding weddings and funerals, where "Never"="0", "About once a year or less"="1", "About once every several months"="2", "About once a month"="3", "About once a week"="4", "More than once a week"="5". Corruption outcomes are respondents' beliefs about how many people are involved in corruption where "None"="0", "Some of them"="1", "Most of them"="2", "All of them"="3". 
Table A1: Summary Statistics, DHS

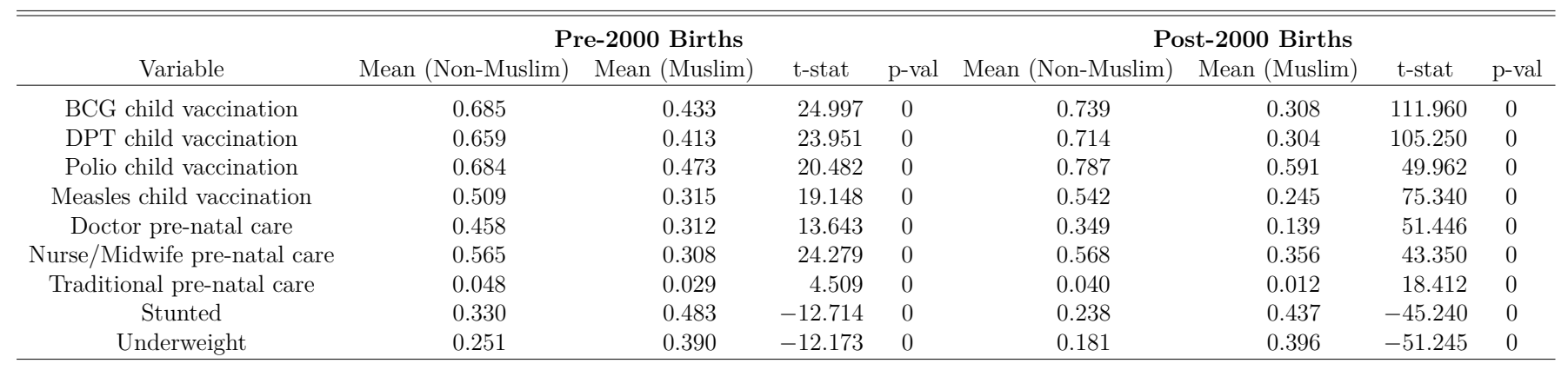

Notes: DHS data from BR dataset includes outcomes for birth years from 1985-2013 and survey years from 1990-2013.
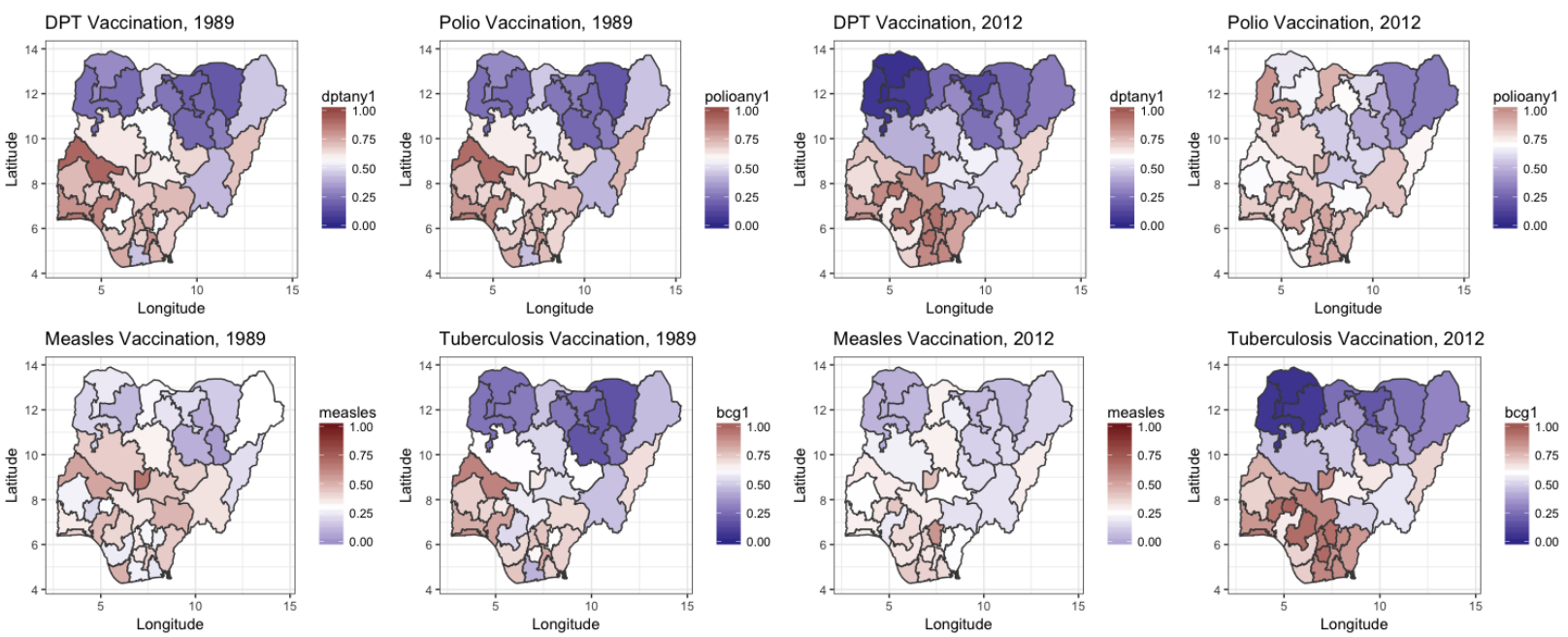

Figure A3: Share of children born in 1989 and 2012 with vaccinations recorded in Nigeria by state. Source: DHS 
Table A2: Reduced form relationship between prior year, t-1, child vaccination coverage and disease incidence in year $\mathrm{t}$ (Panel A) and between Muslim mother status and child vaccination outcomes (Panel B) pre 2000

\begin{tabular}{|c|c|c|c|c|}
\hline \multirow{4}{*}{$\begin{array}{l}\text { Outcome: } \\
\text { Vaccination rate, t-1: }\end{array}$} & \multicolumn{4}{|c|}{ Panel A: Vaccination Coverage and Disease Incidence, 1985-1990 } \\
\hline & \multicolumn{2}{|c|}{ BCG Cases, $\mathrm{t}$} & \multicolumn{2}{|c|}{ Measles Cases, $\mathrm{t}$} \\
\hline & $(\mathrm{BCG} 90 \%)$ & (BCG 50\%) & (Measles 90\%) & (Measles 50\%) \\
\hline & $(1)$ & $(2)$ & (3) & $(4)$ \\
\hline Vaccination rate, $\mathrm{t}-1(\%)$ & $\begin{array}{l}-16.796^{* * *} \\
\quad(6.277)\end{array}$ & $\begin{array}{c}5.815 \\
(11.125)\end{array}$ & $\begin{array}{l}-93.484^{* *} \\
(46.704)\end{array}$ & $\begin{array}{c}17.374 \\
(23.994)\end{array}$ \\
\hline Mean of outcome & 35.100 & 35.100 & 176.700 & 176.700 \\
\hline Observations & 192 & 192 & 192 & 193 \\
\hline Clusters & 35 & 35 & 35 & 35 \\
\hline State FE & Yes & Yes & Yes & Yes \\
\hline Year FE & Yes & Yes & Yes & Yes \\
\hline \multirow{3}{*}{ Outcome: } & \multicolumn{4}{|c|}{ Panel B: Muslim Mothers and Child Vaccination Outcomes, 1985-199! } \\
\hline & BCG & DPT & Polio & Measles \\
\hline & $(1)$ & $(2)$ & $(3)$ & $(4)$ \\
\hline Muslim & $\begin{array}{c}0.017 \\
(0.020)\end{array}$ & $\begin{array}{c}0.020 \\
(0.020)\end{array}$ & $\begin{array}{c}0.024 \\
(0.020)\end{array}$ & $\begin{array}{c}0.017 \\
(0.021)\end{array}$ \\
\hline Mean of outcome & 0.550 & 0.527 & 0.571 & 0.405 \\
\hline Observations & 9,167 & 8,863 & 8,872 & 9,095 \\
\hline Clusters & 375 & 374 & 375 & 373 \\
\hline Mother's controls & Yes & Yes & Yes & Yes \\
\hline District FE & Yes & Yes & Yes & Yes \\
\hline Year of birth FE & Yes & Yes & Yes & Yes \\
\hline State $\mathrm{x}$ Year FE & Yes & Yes & Yes & Yes \\
\hline
\end{tabular}

Notes: OLS regressions. In Panel A, observations are individual states from 1985-1990 years of available data and robust standard errors in parentheses are clustered by state. In Panel A, dependent variables are cases per 100,000 population of tuberculosis (BCG) and measles in year t. Each column denotes a separate regression. Vaccination rate, t-1 is an indicator that equals one if the share of children born in a given year, $\mathrm{t}-1$, and vaccinated in the state for BCG or measles is above $\mathrm{x} \%$ in the previous year $\mathrm{t}-1$, where the percentage is donated in the parentheses. In Panel B, observations are individual mother responses from 1985-1999, and robust standard errors in parentheses are clustered by district. Districts are local government areas (LGAs) in Nigeria. Dependent variables are child vaccination outcomes for tuberculosis (BCG), diphtheria, pertussis and tetanus (DPT) and polio and measles as described in text. Mother's controls include mother's age at birth and level of education. Muslim is an indicator that equals one if the mother reports that she is Muslim. ${ }^{* * *}$ Significant at the 1 percent level, ${ }^{* *}$ Significant at the 5 percent level, ${ }^{*}$ Significant at the 10 percent level. 
Table A3: Summary Statistics including Afrobarometer outcomes

\begin{tabular}{ccccc}
\hline \hline Variable & Mean (Non-Muslim) & Mean (Muslim) & t-stat & p-val \\
\hline & DHS Survey Outcomes, 1985-2013 & & \\
Age at first marriage & 18.70 & 15.57 & 189.68 & 0 \\
Educated & 0.78 & 0.23 & 319.08 & 0 \\
Level of Education & 1.29 & 0.34 & 289.01 & 0 \\
BCG child vaccination & 0.73 & 0.33 & 113.21 & 0 \\
DPT child vaccination & 0.71 & 0.32 & 106.84 & 0 \\
Polio child vaccination & 0.77 & 0.58 & 53.76 & 0 \\
Measles child vaccination & 0.54 & 0.26 & 77.40 & 0 \\
Doctor pre-natal care & 0.37 & 0.17 & 55.56 & 0 \\
Nurse/Midwife pre-natal care & 0.57 & 0.35 & 49.89 & 0 \\
Traditional pre-natal care & 0.04 & 0.01 & 18.56 & 0 \\
Stunted & 0.25 & 0.44 & -46.79 & 0 \\
Underweight & 0.19 & 0.40 & -52.35 & 0 \\
\hline Afrobarometer Trust and Religiosity & Outcomes, 2003-2014 & \\
Religiosity & 4.059 & 4.086 & -0.803 & 0.422 \\
Trust Neighbors & 1.143 & 1.679 & -18.816 & 0 \\
Trust Relatives & 1.791 & 2.219 & -14.223 & 0 \\
Trust Religious & 1.702 & 1.913 & -4.905 & 0 \\
Trust Police & 0.596 & 0.838 & -14.842 & 0 \\
Trust Local Gov. & 0.805 & 1.129 & -17.596 & 0 \\
Corrupt Religious & 1.201 & 0.943 & 10.357 & 0 \\
Corrupt Police & 2.130 & 2.010 & 6.586 & 0 \\
Corrupt Local Gov. & 1.813 & 1.678 & 7.652 & 0 \\
\hline
\end{tabular}

Notes: DHS data from BR dataset includes outcomes for birth years from 1985-2013 and survey years from 1990-2013. Trust variables are from the Afrobarometer samples over 2003 to 2014. Trust outcomes are reported trust levels on a scale of 0-3, where "Not at all" $=$ " $0 "$ ", "Just a little"="1", "Somewhat"="2", "A lot"="3". Corruption outcomes are respondents' beliefs about how many people are involved in corruption where "None"="0", "Some of them"="1", "Most of them"="2", "All of them"=" $3 "$. Religiosity is reported frequency of religious service attendance, excluding weddings and funerals, where "Never"="0", "About once a year or less"="1", "About once every several months"="2", "About once a month"="3", "About once a week"="4", "More than once a week"=" $5 "$. 


\section{A.3 Robustness}
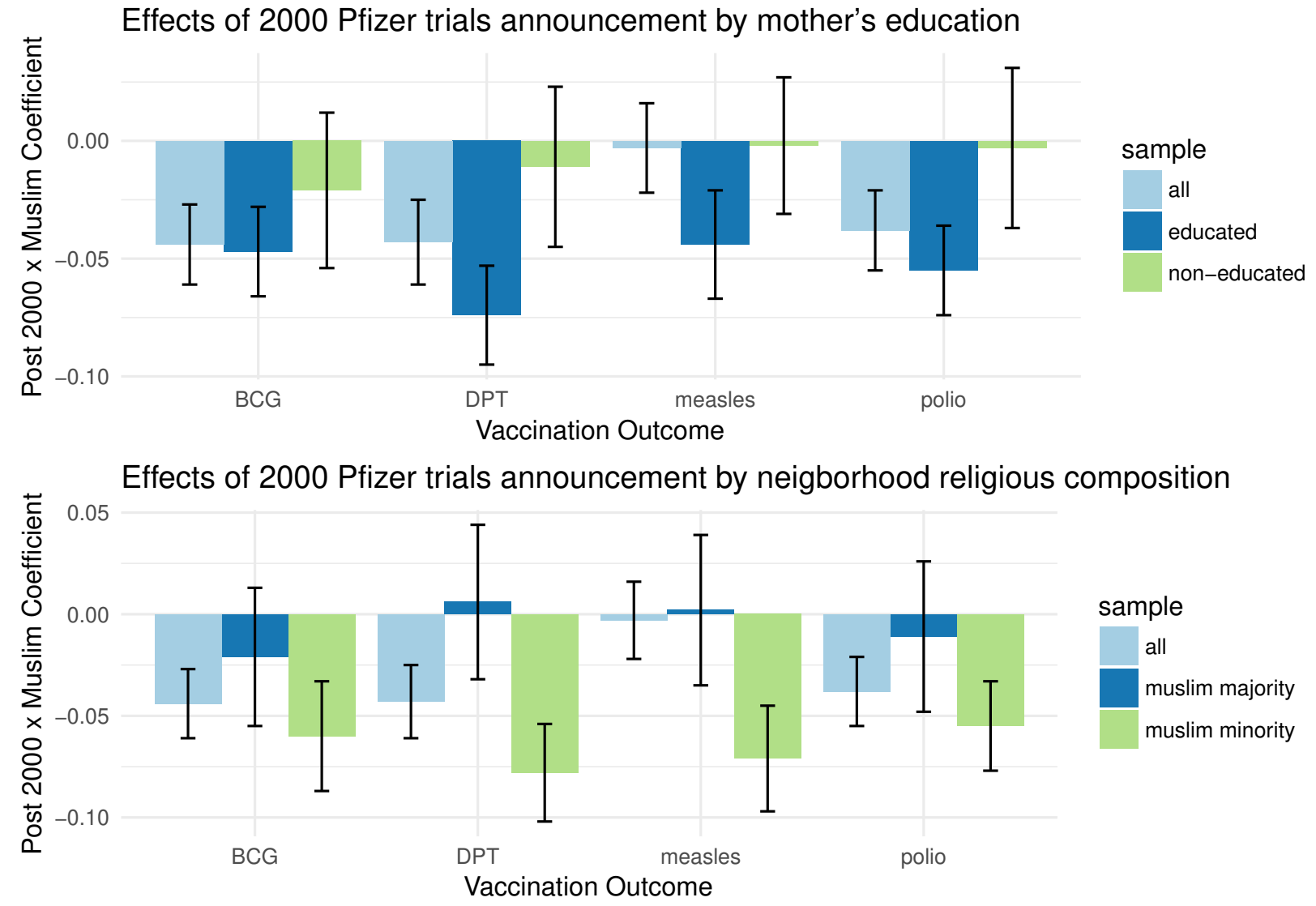

Figure A4: Effect of 2000 Pfizer trials announcement by mother's education and neighborhood religious composition 
Table A4: Effects of 2000 Pfizer trial announcement on child vaccination outcomes, showing main effects

\begin{tabular}{lccccc}
\hline \hline & \multicolumn{5}{c}{ Panel A: Child Vaccination Outcomes: BCG } \\
Sample Within: & All & Educated & Non-Educated & Minority Muslim & Majority Muslim \\
& $(1)$ & $(2)$ & $(3)$ & $(4)$ & $(5)$ \\
\hline Muslim & 0.026 & $0.045^{* *}$ & 0.001 & $0.042^{*}$ & -0.000 \\
Post 2000 x Muslim & $(0.017)$ & $(0.018)$ & $(0.030)$ & $(0.024)$ & $(0.030)$ \\
& $-0.044^{* *}$ & $-0.047^{* *}$ & -0.021 & $-0.060^{* *}$ & -0.021 \\
Mean of outcome & $(0.017)$ & $(0.019)$ & $(0.033)$ & $(0.027)$ & $(0.034)$ \\
Observations & 0.503 & 0.745 & 0.248 & 0.747 & 0.313 \\
Clusters & 66,243 & 33,955 & 32,288 & 28,904 & 37,339 \\
& 710 & 687 & 629 & 380 & 330 \\
\hline
\end{tabular}

\begin{tabular}{lccccc}
\hline \multirow{2}{*}{ Sample Within: } & \multicolumn{5}{c}{ Panel B: Child Vaccination Outcomes: DPT } \\
& All & Educated & Non-Educated & Minority Muslim & Majority Muslim \\
& $(1)$ & $(2)$ & $(3)$ & $(4)$ & $(5)$ \\
\hline Muslim & 0.021 & $0.054^{* * *}$ & 0.003 & $0.043^{* *}$ & -0.021 \\
Post 2000 x Muslim & $(0.017)$ & $(0.019)$ & $(0.031)$ & $(0.022)$ & $(0.035)$ \\
& $-0.043^{* *}$ & $-0.074^{* * *}$ & -0.011 & $-0.078^{* * *}$ & 0.006 \\
Mean of outcome & $(0.018)$ & $(0.021)$ & $(0.034)$ & $(0.024)$ & $(0.038)$ \\
Observations & 0.487 & 0.715 & 0.247 & 0.720 & 0.307 \\
Clusters & 65,752 & 33,691 & 32,061 & 28,633 & 37,119 \\
\hline
\end{tabular}

\begin{tabular}{lccccc}
\hline & \multicolumn{5}{c}{ Panel C: Child Vaccination Outcomes: Polio } \\
Sample Within: & All & Educated & Non-Educated & Minority Muslim & Majority Muslim \\
& $(1)$ & $(2)$ & $(3)$ & $(4)$ & $(5)$ \\
\hline Muslim & $0.033^{* *}$ & $0.047^{* * *}$ & 0.017 & $0.047^{* *}$ & 0.005 \\
& $(0.016)$ & $(0.018)$ & $(0.031)$ & $(0.022)$ & $(0.033)$ \\
Post 2000 x Muslim & $-0.038^{* *}$ & $-0.055^{* * *}$ & -0.003 & $-0.055^{* *}$ & $(0.022)$ \\
& $(0.017)$ & $(0.019)$ & $(0.034)$ & & $0.037)$ \\
Mean of outcome & & & & 0.781 & 0.572 \\
Observations & 0.664 & 0.792 & 0.528 & 28,658 & 36,693 \\
Clusters & 65,351 & 33,632 & 31,719 & 380 & 330 \\
\hline
\end{tabular}

\begin{tabular}{|c|c|c|c|c|c|}
\hline \multirow{3}{*}{ Sample Within: } & \multicolumn{5}{|c|}{ Panel D: Child Vaccination Outcomes: Measles } \\
\hline & All & Educated & Non-Educated & Minority Muslim & Majority Muslim \\
\hline & (1) & $(2)$ & $(3)$ & $(4)$ & $(5)$ \\
\hline \multirow[t]{2}{*}{ Muslim } & -0.019 & 0.014 & 0.012 & $0.044^{*}$ & -0.032 \\
\hline & $(0.017)$ & $(0.022)$ & $(0.027)$ & $(0.025)$ & $(0.032)$ \\
\hline \multirow[t]{2}{*}{ Post 2000 x Muslim } & -0.003 & $-0.044^{*}$ & -0.002 & $-0.071^{* * *}$ & 0.002 \\
\hline & $(0.019)$ & $(0.023)$ & $(0.029)$ & $(0.026)$ & $(0.037)$ \\
\hline Mean of outcome & 0.379 & 0.548 & 0.201 & 0.545 & 0.250 \\
\hline Observations & 65,865 & 33,724 & 32,141 & 28,722 & 37,143 \\
\hline Clusters & 710 & 687 & 629 & 380 & 330 \\
\hline Mother's controls & Yes & Yes & Yes & Yes & Yes \\
\hline District FE & Yes & Yes & Yes & Yes & Yes \\
\hline Year of birth FE & Yes & Yes & Yes & Yes & Yes \\
\hline State x Year FE & Yes & Yes & Yes & Yes & Yes \\
\hline
\end{tabular}

Notes: Regressions estimated by OLS. Robust standard errors in parentheses clustered by district. Districts are local government areas (LGAs) in Nigeria. Dependent variables are child vaccination outcomes for tuberculosis (BCG), diphtheria, pertussis and tetanus (DPT) and polio and measles as described in text. Sample is split between respondents living in districts that are over $50 \%$ muslim or Muslim Majority and respondents living in districts with $<=50 \%$ muslims or Muslim Minority districts in labeled columns. Post 2000 is an indicator that equals 1 if the child's year of birth is after the 2000 drug trial announcement. Muslim is an indicator that equals one if the mother reports that she is Muslim. Mother's controls include mother's age at birth and level of education, and drops education in

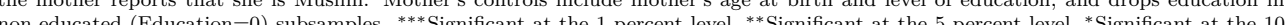
non-educated (Education=0) subsamples. ${ }^{* * *}$ Significant at the 1 percent level, ${ }^{* *}$ Significant at the 5 percent level, ${ }^{*}$ Significant at the 10 percent level. 
Religiosity and trust among Muslims by neigborhood religious composition

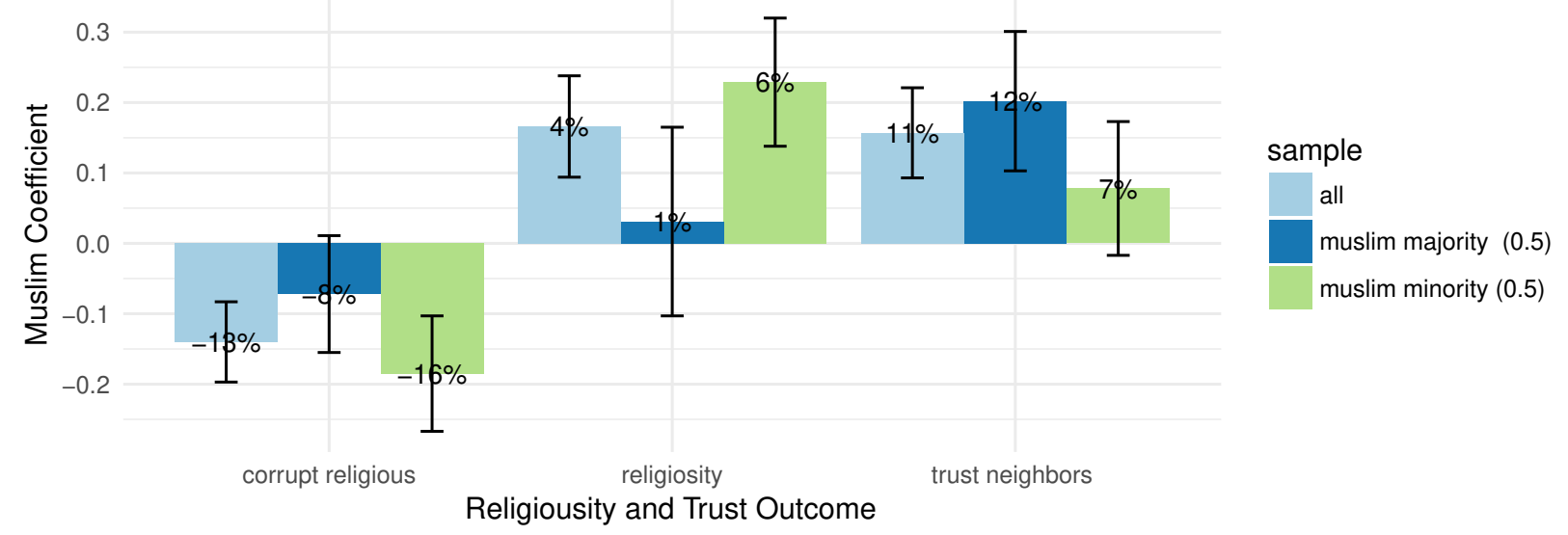

Religiosity and trust among Muslims by neigborhood religious composition

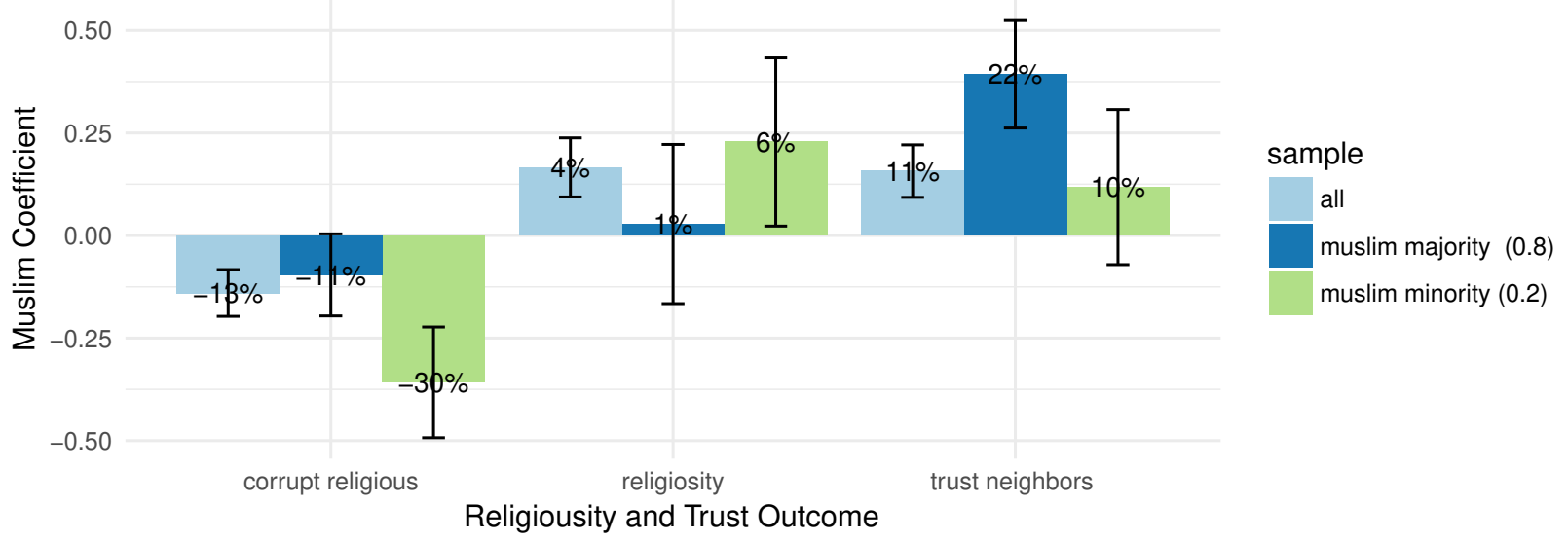

Figure A5: Religiosity and trust among Muslims by neighborhood religious composition 
Table A5: Effects of 2000 Pfizer trial announcement on child vaccination outcomes, heterogeneity tests by minority status of Muslims in district

\begin{tabular}{lccccc}
\hline \hline & \multicolumn{5}{c}{ Panel A: Child Vaccination Outcomes: BCG } \\
Sample Within: & All & $\begin{array}{c}\text { Minority }(<=20 \%) \\
\text { Muslim }\end{array}$ & $\begin{array}{c}\text { Majority }(>80 \%) \\
\text { Muslim }\end{array}$ & $\begin{array}{c}\text { Minority }(<=50 \%) \\
\text { Muslim }\end{array}$ & $\begin{array}{c}\text { Majority }(>50 \%) \\
\text { Muslim }\end{array}$ \\
& $(1)$ & $(2)$ & $(3)$ & $(4)$ & $(5)$ \\
\hline Post 2000 x Muslim & $-0.044^{* *}$ & -0.059 & 0.033 & $-0.060^{* *}$ & -0.021 \\
& $(0.017)$ & $(0.082)$ & $(0.051)$ & $(0.027)$ & $(0.034)$ \\
Observations & 66,243 & 20,725 & 32,002 & 28,904 & 37,339 \\
Clusters & 710 & 293 & 275 & 380 & 330 \\
\hline
\end{tabular}

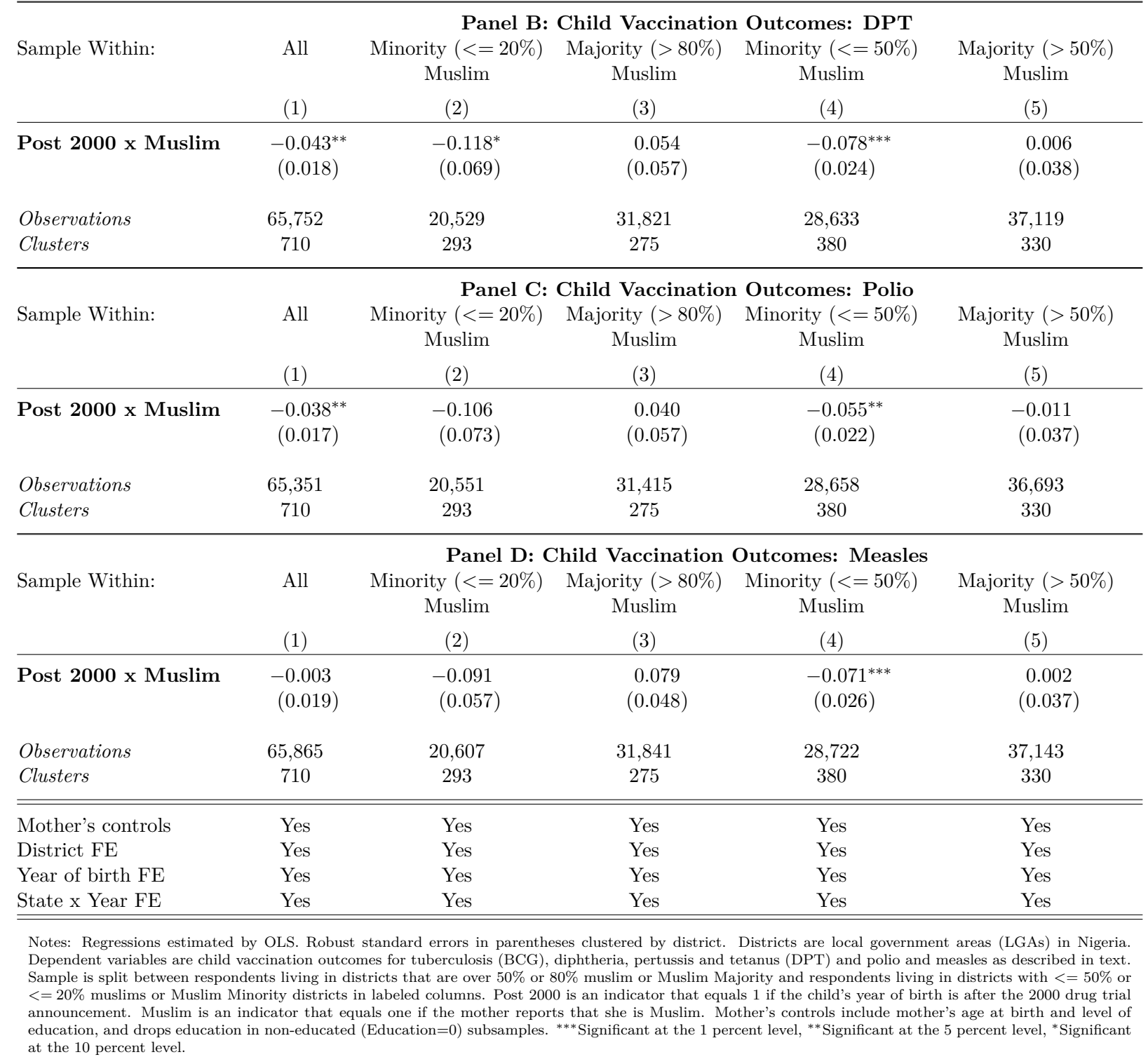


Table A6: Religiosity and trust among Muslims by post 2000 adult cohort status, robustness to marginal changes in age cutoff

\begin{tabular}{|c|c|c|c|c|c|c|}
\hline \multirow{4}{*}{$\begin{array}{l}\text { Outcome: } \\
\text { Sample Within: }\end{array}$} & \multicolumn{6}{|c|}{ Panel A: Muslim respondents, religiosity and trust by Adult ( $>=17$ years) cohort } \\
\hline & \multirow{2}{*}{\multicolumn{3}{|c|}{$\begin{array}{c}\text { Religiosity Corrupt Religious Trust Neighbors } \\
\text { Adult }(>=17 \text { years }) \text { Cohort in } 2000\end{array}$}} & \multirow{3}{*}{$\begin{array}{c}\text { Religiosity } \\
\text { (4) }\end{array}$} & \multirow{2}{*}{$\begin{array}{l}\text { Corrupt Religious } \\
\text { All Cohort }\end{array}$} & \multirow[t]{2}{*}{ Trust Neighbors } \\
\hline & & & & & & \\
\hline & $(1)$ & $(2)$ & $(3)$ & & $(5)$ & $(6)$ \\
\hline Muslim & $0.164^{* *}$ & $-0.134^{* *}$ & $0.165^{* *}$ & 0.082 & $-0.176^{* * *}$ & $0.208^{* * *}$ \\
\hline & $(0.074)$ & $(0.054)$ & $(0.061)$ & $(0.081)$ & $(0.062)$ & $(0.068)$ \\
\hline Post 2000 Adult x Muslim & & & & 0.099 & 0.079 & -0.072 \\
\hline & & & & $(0.074)$ & $(0.059)$ & $(0.064)$ \\
\hline Observations & 4,852 & 2,971 & 3,092 & 6,882 & 4,481 & 4,643 \\
\hline Clusters & 375 & 292 & 325 & 381 & 299 & 326 \\
\hline
\end{tabular}

Outcome:

Sample Within:

Panel B: Muslim respondents, religiosity and trust by Adult ( $>=19$ years) cohort

Religiosity Corrupt Religious Trust Neighbors Religiosity Corrupt Religious Adult ( $>=19$ years) Cohort in 2000

\begin{tabular}{|c|c|c|c|c|c|c|}
\hline & $(1)$ & $(2)$ & $(3)$ & $(4)$ & $(5)$ & $(6)$ \\
\hline Muslim & $\begin{array}{c}0.154^{* *} \\
(0.075)\end{array}$ & $\begin{array}{c}-0.137^{* *} \\
(0.060)\end{array}$ & $\begin{array}{c}0.156^{* *} \\
(0.066)\end{array}$ & $\begin{array}{c}0.051 \\
(0.079)\end{array}$ & $\begin{array}{c}-0.146^{* *} \\
(0.059)\end{array}$ & $\begin{array}{c}0.168^{* * *} \\
(0.059)\end{array}$ \\
\hline Post 2000 Adult x Muslim & & & & $\begin{array}{c}0.165^{* *} \\
(0.076)\end{array}$ & $\begin{array}{c}0.041 \\
(0.057)\end{array}$ & $\begin{array}{c}-0.014 \\
(0.061)\end{array}$ \\
\hline Observations & 4,184 & 2,539 & 2,634 & 6,882 & 4,481 & 4,643 \\
\hline Clusters & 373 & 289 & 325 & 381 & 299 & 326 \\
\hline Individual controls & Yes & Yes & Yes & Yes & Yes & Yes \\
\hline District FE & Yes & Yes & Yes & Yes & Yes & Yes \\
\hline Year of birth FE & Yes & Yes & Yes & Yes & Yes & Yes \\
\hline State $\mathrm{x}$ Year FE & Yes & Yes & Yes & Yes & Yes & Yes \\
\hline
\end{tabular}

Notes: Regressions estimated by OLS. Robust standard errors in parentheses clustered by district. Districts are local government areas (LGAs). Dependent variables are religiosity, trust in religious leaders and trust in neighbors from the Afrobarometer surveys from 2003-2014 where data available. Trust outcomes are reported trust levels on a scale of 0-3, where "Not at all"= "0", "Just a little"="1", "Somewhat"="2", "A lot"="3"; Religiosity is reported frequency of religious service attendance, excluding weddings and funerals, where "Never"="0", "About once a year or less"="1", "About once every several months"="2", "About once a month"="3", "About once a week"="4", "More than once a week"="5". Corruption outcomes are respondents' beliefs about how many people are involved in corruption where "None"="0", "Some of them"="1", "Most of them"="2" "All of them"="3". Individual controls include respondent level of education and gender or an indicator that equals one if the respondent is female. Muslim is an indicator that equals one if the respondent is Muslim; Post 2000 Adult is an indicator that equals one if the respondent was an adult, aged $>=17$ (Panel A) or 20 years (Panel B), in 2000. State x Year FE are included in all specifications except for Corrupt Religious outcomes, which have only one year of data available. ${ }^{* * *}$ Significant at the 1 percent level, ${ }^{*}$ Significant at the 5 percent level, ${ }^{*}$ Significant at the 10 percent level. 
Table A7: Religiosity and trust among Muslims by post 2000 adult cohort and minority status of Muslims in districts

\begin{tabular}{|c|c|c|c|c|c|c|}
\hline \multirow{3}{*}{$\begin{array}{l}\text { Outcome: } \\
\text { Sample Within: }\end{array}$} & \multicolumn{6}{|c|}{ Panel A: Muslim respondents and trust outcomes by minority $(<=50 \%)$ and majority $(>50 \%)$ status } \\
\hline & \multicolumn{4}{|c|}{ Muslim Minority (Adult ( $>=18$ years) Cohort in 2000) } & \multicolumn{2}{|c|}{ Muslim Majority (Adult Cohort in 2000) } \\
\hline & $(1)$ & $(2)$ & $(3)$ & $(4)$ & $(5)$ & $(6)$ \\
\hline Muslim & $\begin{array}{c}0.229^{* *} \\
(0.091)\end{array}$ & $\begin{array}{c}-0.185^{* *} \\
(0.082)\end{array}$ & $\begin{array}{c}0.078 \\
(0.095)\end{array}$ & $\begin{array}{c}0.031 \\
(0.134)\end{array}$ & $\begin{array}{c}-0.072 \\
(0.083)\end{array}$ & $\begin{array}{c}0.202^{* *} \\
(0.099)\end{array}$ \\
\hline Mean of outcome & 4.012 & 1.165 & 1.196 & 3.931 & 0.942 & 1.740 \\
\hline Observations & 2,663 & 1,636 & 1,645 & 1,651 & 977 & 1,112 \\
\hline Clusters & 209 & 163 & 172 & 141 & 109 & 130 \\
\hline
\end{tabular}

\begin{tabular}{|c|c|c|c|c|c|c|}
\hline \multirow{4}{*}{$\begin{array}{l}\text { Outcome: } \\
\text { Sample Within: }\end{array}$} & \multicolumn{6}{|c|}{ Panel B: Muslim respondents and trust outcomes by minority $(<=20 \%)$ and majority $(>80 \%)$ status } \\
\hline & \multirow{2}{*}{\multicolumn{3}{|c|}{$\begin{array}{l}\text { Religiosity Corrupt Religious Trust Neighbors } \\
\text { Muslim Minority (Adult ( }>=18 \text { years) Cohort in 2000) }\end{array}$}} & \multirow[t]{2}{*}{ Religiosity } & \multirow{2}{*}{\multicolumn{2}{|c|}{$\begin{array}{c}\text { Corrupt Religious } \quad \text { Trust Neighbors } \\
\text { Muslim Majority (Adult Cohort in 2000) }\end{array}$}} \\
\hline & & & & & & \\
\hline & (1) & $(2)$ & $(3)$ & $(4)$ & $(5)$ & (6) \\
\hline Muslim & $\begin{array}{c}0.228 \\
(0.205)\end{array}$ & $\begin{array}{c}-0.358^{* * *} \\
(0.135)\end{array}$ & $\begin{array}{c}0.118 \\
(0.189)\end{array}$ & $\begin{array}{c}0.028 \\
(0.194)\end{array}$ & $\begin{array}{r}-0.096 \\
(0.100)\end{array}$ & $\begin{array}{l}0.393^{* * *} \\
(0.131)\end{array}$ \\
\hline Mean of outcome & 3.848 & 1.196 & 1.235 & 3.863 & 0.908 & 1.784 \\
\hline Observations & 1,862 & 1,130 & 1,137 & 1,299 & 779 & 882 \\
\hline Clusters & 156 & 115 & 130 & 112 & 87 & 101 \\
\hline Individual controls & Yes & Yes & Yes & Yes & Yes & Yes \\
\hline District FE & Yes & Yes & Yes & Yes & Yes & Yes \\
\hline Year of birth FE & Yes & Yes & Yes & Yes & Yes & Yes \\
\hline State $x$ Year FE & Yes & Yes & Yes & Yes & Yes & Yes \\
\hline
\end{tabular}

Notes: Regressions estimated by OLS. Robust standard errors in parentheses clustered by district. Districts are local government areas (LGAs). Dependent variables are religiosity, trust in religious leaders and trust in neighbors from the Afrobarometer surveys from 2003-2014 where data available. Trust outcomes are reported trust levels on a scale of 0-3, where "Not at all" = "0", "Just a little"="1", "Somewhat"="2", "A lot"="3"; Religiosity is reported frequency of religious service attendance, excluding weddings and funerals, where "Never"="0", "About once a year or less"=" 1 ", "About once every several months" $=2$," About once a month" $=3$ ", "About once a week" $=4 "$, "More than once a week" $=$ " 5 ". Corruption outcomes are respondents" beliefs about how many people are involved in corruption where "None" $=" 0$ ", "Some of them" $=" 1$, "Most of them" $=" 2$ ", "All of them" $=" 3$ ". Individual controls include respondent level of education and gender or an indicator that equals one if the respondent is female. Muslim is an indicator that equals one if the respondent is Muslim; post 2000 is an indicator that equals one if the respondent was an adult, aged $>=18$ years, in 2000 . State x Year FE are included in all specifications except for Corrupt Religious outcomes, which have only one year of data available. ${ }^{* * *}$ Significant at the 1 percent level, ${ }^{* *}$ Significant at the 5 percent level, * Significant at the 10 percent level. 
Table A8: Trust in religious leaders and child vaccination outcomes in 2012

Covariate:

Panel: Trust in religious leaders and child vaccination outcomes in 2012

Muslim x Muslim x Muslim x

Trust Religious D Religiosity D Trust Neighbors D

Muslim x

Trust Police D

(1)

\begin{tabular}{|c|c|c|c|c|}
\hline $\mathrm{BCG}$ & $\begin{array}{c}-0.161^{* * *} \\
(0.059)\end{array}$ & $\begin{array}{c}-0.042 \\
(0.057)\end{array}$ & $\begin{array}{c}-0.046 \\
(0.078)\end{array}$ & $\begin{array}{r}-0.095 \\
(0.084)\end{array}$ \\
\hline Mean of outcome & 0.614 & 0.614 & 0.608 & 0.614 \\
\hline $\mathrm{DPT}$ & $\begin{array}{c}-0.133^{* * *} \\
(0.048)\end{array}$ & $\begin{array}{r}-0.111^{*} \\
(0.058)\end{array}$ & $\begin{array}{c}-0.005 \\
(0.077)\end{array}$ & $\begin{array}{r}-0.068 \\
(0.081)\end{array}$ \\
\hline Mean of outcome & 0.591 & 0.591 & 0.579 & 0.591 \\
\hline Polio & $\begin{array}{r}-0.038 \\
(0.047)\end{array}$ & $\begin{array}{c}-0.135^{* *} \\
(0.065)\end{array}$ & $\begin{array}{c}-0.035 \\
(0.081)\end{array}$ & $\begin{array}{r}-0.059 \\
(0.122)\end{array}$ \\
\hline Mean of outcome & 0.766 & 0.766 & 0.730 & 0.766 \\
\hline Measles & $\begin{array}{r}-0.092^{*} \\
(0.054)\end{array}$ & $\begin{array}{r}-0.047 \\
(0.052)\end{array}$ & $\begin{array}{c}0.013 \\
(0.077)\end{array}$ & $\begin{array}{r}-0.036 \\
(0.078)\end{array}$ \\
\hline Mean of outcome & 0.256 & 0.256 & 0.279 & 0.256 \\
\hline Mother's controls & Yes & Yes & Yes & Yes \\
\hline State FE & Yes & Yes & Yes & Yes \\
\hline
\end{tabular}

Notes: Regressions estimated by OLS. Robust standard errors in parentheses clustered by district. Districts are local government areas (LGAs). Dependent variables are child vaccination outcomes from the DHS for children born in 2012. Covariates are Muslim x Trust D variables with trust variables from the Afrobarometer survey in 2012 (and closest year 2014 for religious data where 2012 data is not available). Trust D variables are indicators that equal one if trust is greater than 1; Religiosity D is an indicator that equals 1 if religiosity measure is greater than the sample median 4.7. Mother's controls include mother's age at birth and level of education. Muslim is an indicator that equals one if the respondent is Muslim. State FE are included in all specifications.

${ }^{* * *}$ Significant at the 1 percent level, ${ }^{* *}$ Significant at the 5 percent level, ${ }^{*}$ Significant at the 10 percent level. 
Table A9: Effects of 2000 Pfizer trial announcement on mother's health-seeking behavior (pre-natal care) and other child health outcomes

\begin{tabular}{|c|c|c|c|c|c|c|c|c|c|}
\hline \multirow{4}{*}{$\begin{array}{l}\text { Outcome: } \\
\text { Sample Within: }\end{array}$} & \multicolumn{9}{|c|}{ Panel A: Mother's Pre-Natal Care: Doctor, Nurse/Midwife, Traditional } \\
\hline & \multicolumn{3}{|c|}{ Doctor } & \multicolumn{3}{|c|}{ Nurse } & \multicolumn{3}{|c|}{ Traditional } \\
\hline & All & Educated & Non-Educated & All & Educated & Non-Educated & All & Educated & Non-Educated \\
\hline & $(1)$ & $(2)$ & $(3)$ & $(4)$ & $(5)$ & $(6)$ & $(7)$ & $(8)$ & $(9)$ \\
\hline Muslim & $\begin{array}{l}0.062^{* * *} \\
(0.018)\end{array}$ & $\begin{array}{c}0.052^{* *} \\
(0.021)\end{array}$ & $\begin{array}{l}0.092^{* * *} \\
(0.035)\end{array}$ & $\begin{array}{c}0.002 \\
(0.028)\end{array}$ & $\begin{array}{c}-0.019 \\
(0.038)\end{array}$ & $\begin{array}{c}-0.013 \\
(0.035)\end{array}$ & $\begin{array}{c}0.014^{*} \\
(0.009)\end{array}$ & $\begin{array}{c}0.022^{*} \\
(0.012)\end{array}$ & $\begin{array}{c}0.013 \\
(0.012)\end{array}$ \\
\hline Post 2000 x Muslim & $\begin{array}{r}-0.033^{*} \\
(0.020)\end{array}$ & $\begin{array}{c}-0.021 \\
(0.022)\end{array}$ & $\begin{array}{c}-0.079^{* *} \\
(0.036)\end{array}$ & $\begin{array}{c}0.011 \\
(0.028)\end{array}$ & $\begin{array}{c}0.039 \\
(0.039)\end{array}$ & $\begin{array}{c}0.030 \\
(0.038)\end{array}$ & $\begin{array}{c}-0.009 \\
(0.008)\end{array}$ & $\begin{array}{c}-0.015 \\
(0.012)\end{array}$ & $\begin{array}{c}-0.010 \\
(0.013)\end{array}$ \\
\hline Mean of outcome & 0.256 & 0.393 & 0.112 & 0.446 & 0.616 & 0.270 & 0.027 & 0.034 & 0.020 \\
\hline Observations & 49,229 & 25,064 & 24,165 & 49,231 & 25,066 & 24,165 & 49,232 & 25,067 & 24,165 \\
\hline Clusters & 710 & 688 & 632 & 710 & 688 & 632 & 710 & 688 & 632 \\
\hline
\end{tabular}

Panel B: Child Health Outcomes: Stunting, Underweight and Infant Mortality

Outcome: Stunted Underweight Mortality

Sample Within: All Educated Non-Educated All Educated Non-Educated All Educated Non-Educated

\begin{tabular}{|c|c|c|c|c|c|c|c|c|c|}
\hline & $(1)$ & $(2)$ & $(3)$ & $(4)$ & $(5)$ & $(6)$ & $(7)$ & $(8)$ & $(9)$ \\
\hline Muslim & $\begin{array}{c}0.042^{* *} \\
(0.017)\end{array}$ & $\begin{array}{l}0.069^{* * *} \\
(0.022)\end{array}$ & $\begin{array}{c}0.005 \\
(0.028)\end{array}$ & $\begin{array}{c}0.020 \\
(0.017)\end{array}$ & $\begin{array}{r}0.042^{*} \\
(0.022)\end{array}$ & $\begin{array}{c}-0.004 \\
(0.031)\end{array}$ & $\begin{array}{c}-0.005 \\
(0.013)\end{array}$ & $\begin{array}{c}-0.018 \\
(0.020)\end{array}$ & $\begin{array}{c}0.002 \\
(0.021)\end{array}$ \\
\hline Post 2000 x Muslim & $\begin{array}{c}-0.045^{* *} \\
(0.017)\end{array}$ & $\begin{array}{c}-0.061^{* * *} \\
(0.023)\end{array}$ & $\begin{array}{c}-0.031 \\
(0.030)\end{array}$ & $\begin{array}{c}-0.023 \\
(0.017)\end{array}$ & $\begin{array}{r}-0.036^{*} \\
(0.021)\end{array}$ & $\begin{array}{c}-0.022 \\
(0.033)\end{array}$ & $\begin{array}{c}-0.001 \\
(0.012)\end{array}$ & $\begin{array}{c}0.011 \\
(0.019)\end{array}$ & $\begin{array}{c}-0.008 \\
(0.021)\end{array}$ \\
\hline Mean of outcome & 0.357 & 0.259 & 0.469 & 0.302 & 0.207 & 0.412 & 0.408 & 0.471 & 0.376 \\
\hline Observations & 53,043 & 28,352 & 24,691 & 53,043 & 28,352 & 24,691 & 41,932 & 14,138 & 27,794 \\
\hline Clusters & 710 & 683 & 625 & 710 & 683 & 625 & 706 & 665 & 601 \\
\hline Mother's controls & Yes & Yes & Yes & Yes & Yes & Yes & Yes & Yes & Yes \\
\hline District FE & Yes & Yes & Yes & Yes & Yes & Yes & Yes & Yes & Yes \\
\hline Year of birth FE & Yes & Yes & Yes & Yes & Yes & Yes & Yes & Yes & Yes \\
\hline State $\mathrm{x}$ Year FE & Yes & Yes & Yes & Yes & Yes & Yes & Yes & Yes & Yes \\
\hline
\end{tabular}

Notes: Regressions estimated by OLS. Robust standard errors in parentheses clustered by district. Districts are local government areas (LGAs) in Nigeria. Dependent variables are mother's reported pre-natal care source: doctors, nurses/midwives or traditional healers, in Panel A; In Panel B, dependent variables are current child health outcomes for stunting and underweight in columns (1) to (6). A child is considered underweight by WHO standards if they have a weight for age $\mathrm{z}$-score (WFA $\mathrm{z}$ ) of less than -2.0 while a child is considered stunted with a height for age $\mathrm{z}$-score (HFA $\mathrm{z}$ ) of less than -2.0. Infant mortality is the outcome in columns (7) to (9) or Panel B. Post 2000 is an indicator that equals 1 if the child s year of birth is after the 2000 drug trial announcement. Muslim is an indicator that equals one if the mother reports level, ** Significant at the 5 percent level ${ }^{*}$ Significant at the 10 percent level. 


\section{A.4 Health Facility Statistics}

Below are health infrastructure quality measures by state from a 2012 health facility dataset in Nigeria. The health facility dataset comes from an effort spearheaded by the Nigerian government and researchers from the country's Office of the Senior Special Assistant to the President on MDGs (OSSAP), in collaboration with the Sustainable Engineering Lab at Columbia University who conducted extensive, comprehensive surveys of schools and health facilities at local government areas (LGAs) in Nigeria. According to the Federal Ministry of Health, Nigeria had 34,423 health facilities as of 2013 (Makinde et al., 2018). Thus, the health facility sample represents about $70 \%$ of the universe of health facilities in Nigeria. The health quality infrastructure index is an average of 8 public services reported available at the health facility in each LGA and state in Nigeria, namely: the share of facilities with ante-natal services, family planning services, emergency transport, a freezer for vaccines, vaccines at the facility, caesarian services, improved water supply and grid power access.
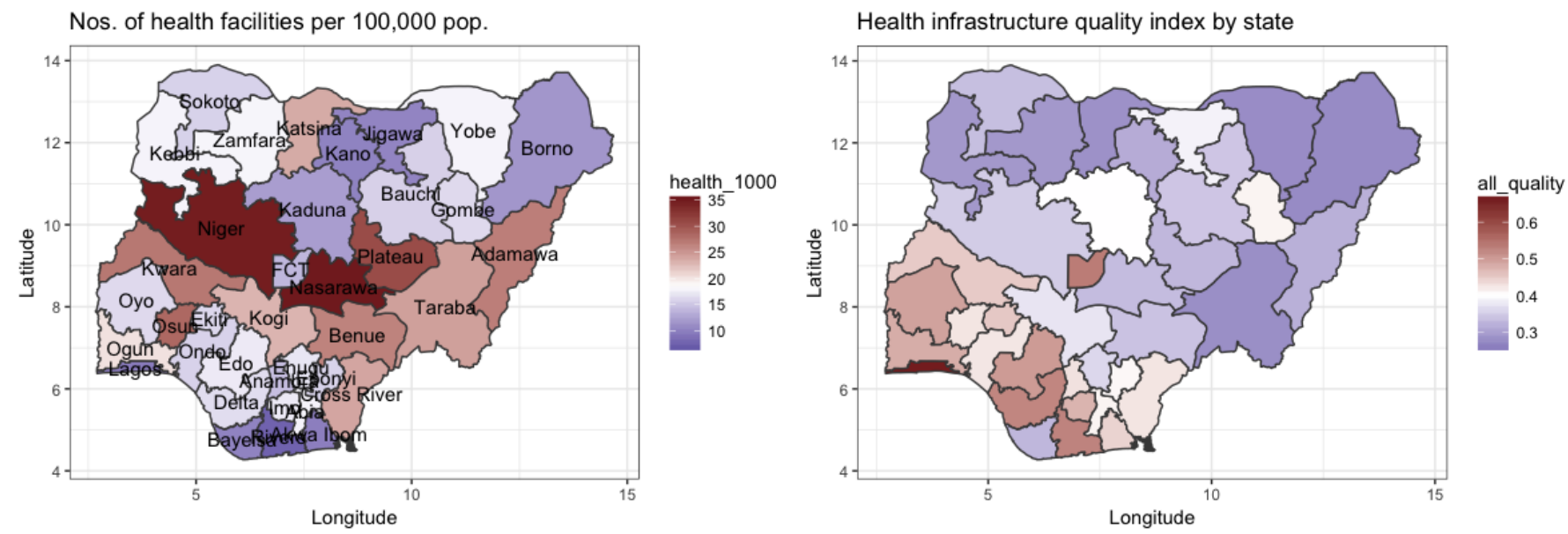

Figure A6: Number of health facilities per 100,000 population and health infrastructure quality index by state, 2012. Source: OSSAP survey 

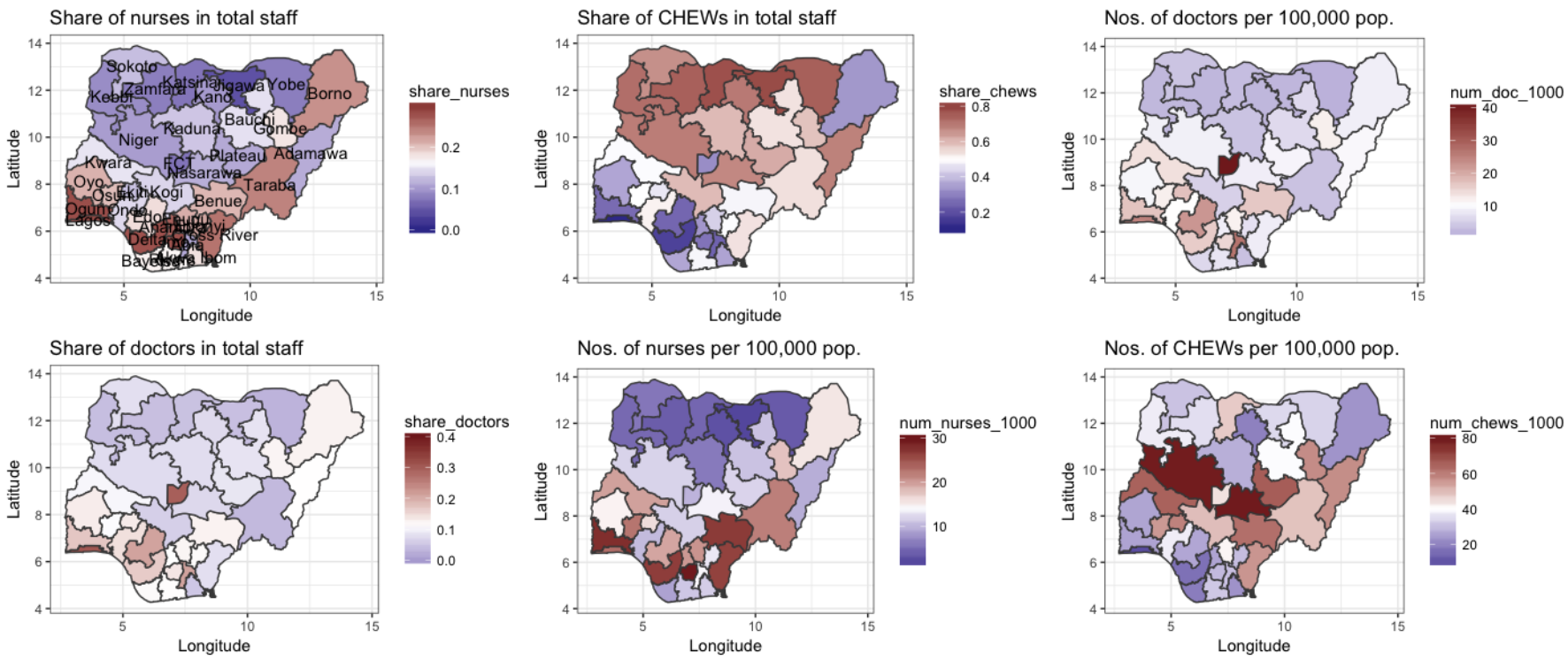

Figure A7: Staff availability at health facilities by state, 2012. Source: OSSAP survey

Table A10: Increase in share of nurse/midwives in total health personnel by Muslim state status post 2000

\begin{tabular}{|c|c|c|c|c|c|c|}
\hline \multirow{2}{*}{$\begin{array}{l}\text { Covariate: } \\
\text { Outcome: }\end{array}$} & \multicolumn{3}{|c|}{ Muslim Share Continuous } & \multicolumn{3}{|c|}{ Muslim Majority Indicator } \\
\hline & $\begin{array}{c}\text { Share Nurse } \\
(1)\end{array}$ & $\begin{array}{c}\text { Share Doctor } \\
(2)\end{array}$ & $\begin{array}{c}\text { Share CHEW } \\
(3)\end{array}$ & $\begin{array}{c}\text { Share Nurse } \\
(4)\end{array}$ & $\begin{array}{c}\text { Share Doctor } \\
(5)\end{array}$ & $\begin{array}{c}\text { Share CHEW } \\
(6)\end{array}$ \\
\hline Muslim Share & $\begin{array}{c}0.034 \\
(0.074)\end{array}$ & $\begin{array}{c}0.155^{* *} \\
(0.071)\end{array}$ & $\begin{array}{r}-0.163^{*} \\
(0.095)\end{array}$ & $\begin{array}{c}-0.033 \\
(0.061)\end{array}$ & $\begin{array}{c}0.027 \\
(0.020)\end{array}$ & $\begin{array}{c}0.020 \\
(0.074)\end{array}$ \\
\hline Post 2000 x Muslim Share & $\begin{array}{l}0.058^{* *} \\
(0.026)\end{array}$ & $\begin{array}{c}-0.024 \\
(0.017)\end{array}$ & $\begin{array}{c}0.067^{*} \\
(0.041)\end{array}$ & $\begin{array}{c}0.048^{* *} \\
(0.021)\end{array}$ & $\begin{array}{r}-0.029^{*} \\
(0.017)\end{array}$ & $\begin{array}{c}0.053 \\
(0.035)\end{array}$ \\
\hline Mean of outcome & 0.428 & 0.099 & 0.387 & 0.428 & 0.099 & 0.387 \\
\hline Observations & 71 & 71 & 71 & 71 & 71 & 71 \\
\hline State FE & Yes & Yes & Yes & Yes & Yes & Yes \\
\hline Year FE & Yes & Yes & Yes & Yes & Yes & Yes \\
\hline
\end{tabular}

Notes: Regressions estimated by OLS. Robust standard errors in parentheses clustered by state. State and year fixed effects included in all specifications. Dependent variables are share nurse/midwives, share doctors and share community health extension workers (CHEWs) in total health personnel (where total health personnel is sum of nurses/midwives, doctors and CHEWs) in 1991 and 2012 datasets. Muslim Share is the share of respondents in a state who are muslim in the 1990 and 2013 DHS for 1991 and 2012 respectively. The Muslim Majority Indicator an indicator that equals 1 if the share muslim is greater than $50 \%$ in a state. ${ }^{* * *}$ Significant at the 1 percent level, ${ }^{* *}$ Significant at the 5 percent level, *Significant at the 10 percent level. 